

\section{COFFEE IN HEALTH AND DISEASE PREVENTION}


This page intentionally left blank 


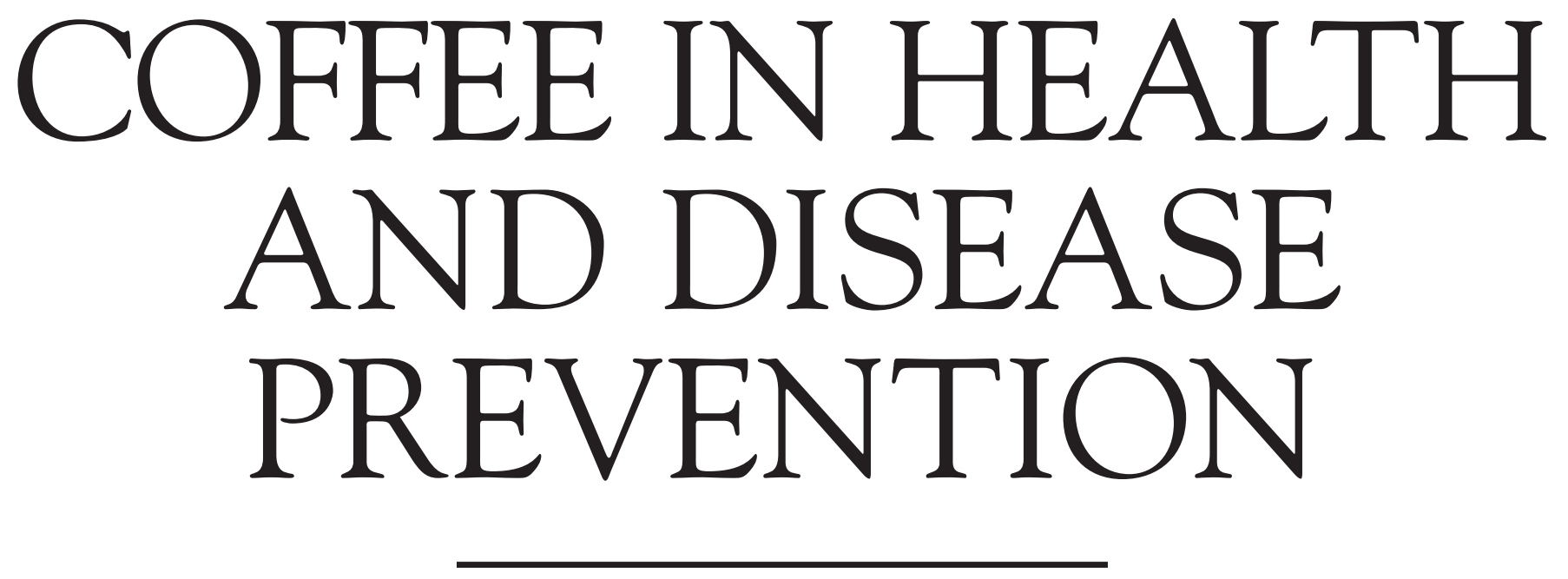

Edited by

Victor R. PReEdy

Department of Nutrition and Dietetics, King's College London, London, UK 
Academic Press is an imprint of Elsevier

32 Jamestown Road, London NW1 7BY, UK

525 B Street, Suite 1800, San Diego, CA 92101-4495, USA

225 Wyman Street, Waltham, MA 02451, USA

The Boulevard, Langford Lane, Kidlington, Oxford OX5 1GB, UK

Copyright (c) 2015 Elsevier Inc. All rights reserved.

Medicine is an ever-changing field. Standard safety precautions must be followed, but as new research and clinical experience broaden our knowledge, changes in treatment and drug therapy may become necessary or appropriate. Readers are advised to check the most current product information provided by the manufacturer of each drug to be administered to verify the recommended dose, the method and duration of administrations, and contraindications. It is the responsibility of the treating physician, relying on experience and knowledge of the patient, to determine dosages and the best treatment for each individual patient. Neither the publisher nor the authors assume any liability for any injury and/or damage to persons or property arising from this publication.

No part of this publication may be reproduced or transmitted in any form or by any means, electronic or mechanical, including photocopying, recording, or any information storage and retrieval system, without permission in writing from the publisher. Details on how to seek permission, further information about the Publisher's permissions policies and our arrangements with organizations such as the Copyright Clearance Center and the Copyright Licensing Agency, can be found at our website: www.elsevier.com/permissions.

This book and the individual contributions contained in it are protected under copyright by the Publisher (other than as may be noted herein).

\section{Notices}

Knowledge and best practice in this field are constantly changing. As new research and experience broaden our understanding, changes in research methods, professional practices, or medical treatment may become necessary.

Practitioners and researchers must always rely on their own experience and knowledge in evaluating and using any information, methods, compounds, or experiments described herein. In using such information or methods they should be mindful of their own safety and the safety of others, including parties for whom they have a professional responsibility.

To the fullest extent of the law, neither the Publisher nor the authors, contributors, or editors, assume any liability for any injury and/or damage to persons or property as a matter of products liability, negligence or otherwise, or from any use or operation of any methods, products, instructions, or ideas contained in the material herein.

ISBN: 978-0-12-409517-5

British Library Cataloguing-in-Publication Data

A catalogue record for this book is available from the British Library

Library of Congress Cataloging-in-Publication Data

A catalog record for this book is available from the Library of Congress

For information on all Academic Press publications

visit our website at http:/ / store.elsevier.com/

Typeset by TNQ Books and Journals

www.tnq.co.in

Printed and bound in United States of America

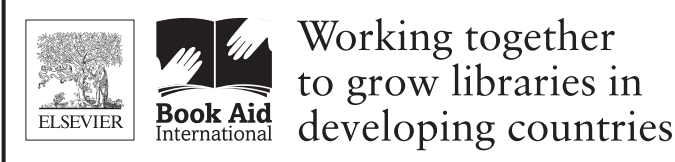

www.elsevier.com • www.bookaid.org 


\section{Contents}

Contributors $\mathrm{xxi}$

Preface xxix

Biography xxxi

\section{SECTION 1}

\section{INTRODUCTORY AND GENERAL TEXT}

\section{Part 1.1 The Plant}

1. The Coffee Plant and Beans: An Introduction ADRIANA FARAH, THIAGO FERREIRA DOS SANTOS

1.1 The Plant 5

1.2 Green Coffee Production 7

1.3 Summary Points 9

References 10

2. Highlights in the History of Coffee Science Related to Health

MARIA LETÍCIA GALLUZZI BIZZO, ADRIANA FARAH, JULIE ANN KEMP, LUIZA BERGUININS SCANCETTI

2.1 Introduction 11

2.2 Coffee, Health, and Science 11

2.3 Main Bioactive Substances in Coffee 13

2.4 Implications of the Amount Consumed 13

2.5 Coffee and Associated Habits 14

2.6 Effects Related to Organs and Diseases 14

2.7 Coffee and Nutrition 15

2.8 Concluding Remarks 16

2.9 Summary Points 16

References 16

3. Plant Biochemistry: Trigonelline Biosynthesis in Coffea arabica and Coffea canephora HIROSHI ASHIHARA

3.1 Introduction 19

3.2 Secondary Metabolites Produced in Coffee Plants 19

3.3 Occurrence of Trigonelline 20

3.4 Biosynthesis of Trigonelline 20

3.5 Degradation of Trigonelline 22

3.6 Physiological Aspects of Trigonelline Metabolism in Coffee 22

3.7 Summary Points 27

References 27
4. Coffea Genome Organization and Evolution

PERLA HAMON, SERGE HAMON, NOROSOA J. RAZAFINARIVO, ROMAIN GUYOT, SONJA SILJAK-YAKOVLEV, EMMANUEL COUTURON, DOMINIQUE CROUZILLAT, MICHEL RIGOREAU, SÉLASTIQUE AKAFFOU, JEAN-JACQUES RAKOTOMALALA, ALEXANDRE DE KOCHKO

4.1 Introduction 29

4.2 Genomic Divergence 29

4.3 Genetic Diversity Based on Transposable

Elements 34

4.4 Summary Points 36

References 36

5. Caffeine-free Species in the Genus Coffea

PERLA HAMON, JEAN-JACQUES RAKOTOMALALA, SÉLASTIQUE AKAFFOU, NOROSOA J. RAZAFINARIVO, EMMANUEL COUTURON, ROMAIN GUYOT, DOMINIQUE CROUZILLAT, SERGE HAMON, ALEXANDRE DE KOCHKO

5.1 Introduction 39

5.2 Caffeine Content, Botanical Classification, and Geographical Distribution of the Species 39

5.3 Genetic Control of Caffeine Biosynthesis 43

5.4 Caffeine Content and Duration of the FloweringFructification Period 43

5.5 Summary Points 44

References 44

6. Characterization of Coffee Genes Involved in Isoprenoid and Diterpene Metabolic

Pathways

LUIZ FILIPE PROTASIO PEREIRA, SUZANA TIEMI IVAMOTO

6.1 Introduction 45

6.2 Overview of the Isoprenoid Metabolic

Pathway 45

6.3 Chemical Composition and Biochemical Analysis of Diterpenes 47

6.4 Regulatory Enzymes and Candidate Genes Involved in Isoprenoid and Diterpene Biosynthesis 48

6.5 Conclusions 50

6.6 Summary Points 51

References 51

7. Botanical Aspects of the Antioxidant System in Coffee IGOR CESARINO, PAULO MAZZAFERA

7.1 Introduction 53

7.2 Conclusions 59

References 59 
8. Coffee Industry in India: Production to Consumption-A Sustainable Enterprise NAYANI SURYA PRAKASH, JEENA DEVASIA, JAYARAMA, RAMESH KUMAR AGGARWAL

8.1 Introduction 61

8.2 Overview of Indian Coffee Industry 61

8.3 Trends in Coffee Exports and Consumption 62

8.4 Indian Coffees: Quality Perspective 62

8.5 History of Coffee Cultivation in India and Early Cultivated Varieties 62

8.6 Unique Features of Coffee Cultivation in India 63

8.7 Genetic Resources and Diversity of Coffee Gene Pool 64

8.8 Coffee Germplasm in India 64

8.9 Molecular Characterization of Representative Coffee Germplasm Available in India 65

8.10 Coffee Species Endemic to India 65

8.11 Taxonomic Status of Indigenous Psilanthus Species Compared with Coffea Species 65

8.12 Growth Habit and Agronomic Traits of Interest of Indigenous Coffee Species 66

8.13 Genetic Improvement and Commercially Grown Varieties in Indian Context 66

8.14 Future Perspective 67

8.15 Summary Points 69

References 69

\section{Part 1.2 Coffee Processing}

9. Coffee Beans and Processing MAIK KLEINWÄCHTER, GERHARD BYTOF, DIRK SELMAR

9.1 Introduction 73

9.2 The Mode of Processing Influences Coffee Quality 73

9.3 Coffee Seeds Exhibit Active Metabolism during Processing 75

9.4 Seed Germination in the Course of Green Coffee Processing 76

9.5 Green Coffee Beans Suffer Drought Stress while Drying 77

9.6 Material Differences in Differently Processed Green Coffees 78

9.7 Deliberately Influencing the Metabolism of Green Coffee to Improve Its Quality 78

9.8 Conclusion 80

9.9 Summary Points 80 References 80

10. Chemical Changes in the Components of Coffee Beans during Roasting FEIFEI WEI, MASARU TANOKURA

10.1 Introduction 83

10.2 Components in Roasted Coffee Beans 83

10.3 The Roasting Degrees 83

10.4 Changes of Carbohydrates 84

10.5 Changes of Chlorogenic Acids 85

10.6 Changes of Trigonelline 87
10.7 Changes of Proteins and Free Amino Acids 87

10.8 Formation of Aroma Components 88

10.9 Torrefacto Roasting 90

References 90

11. Generating Biomedical Polyphenolic Compounds from Spent Coffee or Silverskin

SOLANGE I. MUSSATTO

11.1 Introduction 93

11.2 Polyphenolic Compounds in Spent Coffee and Silverskin and Benefits for Human Health 93

11.3 Extraction of Phenolic Compounds from Natural Sources 97

11.4 Technologies for Extraction of Polyphenolic Compounds from Spent Coffee 98

11.5 Technologies for Extraction of Polyphenolic Compounds from Coffee Silverskin 102

11.6 Conclusions 102

11.7 Summary Points 104

References 104

\section{Authentication of Coffee Blends}

NATALE G. FREGA, DEBORAH PACETTI, MASSIMO MOZZON, MICHELE BALZANO

12.1 Introduction 107

12.2 Chromatography-Based Analytical Techniques 108

12.3 Spectroscopy-Based Analytical Techniques 113

12.4 Genetic Engineering-Based Analytical Techniques 114

12.5 Summary Points 115

References 115

\section{Part 1.3 Constituents and Composition}

\author{
13. Unsaponifiable Matter of Coffee \\ DEBORAH PACETTI, PAOLO LUCCI, NATALE G. FREGA
}

13.1 Introduction 119

13.2 Analytical Techniques for Oil Extraction and Unsaponifiable Matter Analysis 120

13.3 Composition of Coffee Oil 121

13.4 Unsaponifiable Matter Composition: Influence of Coffee Species and Roasting Process 122

13.5 Summary Points 126

References 126

14. Volatile Chemicals from Thermal Degradation of Less Volatile Coffee Components

TAKAYUKI SHIBAMOTO

14.1 Introduction 129

14.2 Volatile Chemicals Formed from Lipids in Coffee 130

14.3 Volatile Chemicals Formed from Carbohydrates and Sugars in Coffee 131

14.4 Volatile Chemicals Formed in Coffee by Maillard Reaction 132 
14.5 Volatile Compounds Formed from Amino Acids and Proteins 132

14.6 Volatile Chemicals Formed from Quinic Acid, Caffeic Acid, and Chlorogenic Acids 133

14.7 Summary Points 134

References 134

\section{Phenolic Compounds in Coffee Compared to Other Beverages}

MAURICIO A. ROSTAGNO, RENATA M.S. CELEGHINI, ISABEL C.N. DEBIEN, GISLAINE C. NOGUEIRA, MARIA ANGELA A. MEIRELES

15.1 Introduction 137

15.2 Phenolic Compounds in Coffee 137

15.3 Phenolic Compounds in Tea 139

15.4 Phenolic Compounds in Wine 140

15.5 Phenolic Compounds in Fruit Juices 140

15.6 Concluding Remarks 141

15.7 Summary Points 141

References 141

\section{Isoflavones in Coffee}

RITA C. ALVES, CRISTINA M.D. SOARES, M. BEATRIZ P.P. OLIVEIRA

16.1 Introduction 143

16.2 Isoflavones in Coffee 143

16.3 Conclusion 147

16.4 Summary Points 148

Acknowledgments 148

References 148

\section{Organic Compounds in Green Coffee} Beans

FEIFEI WEI, MASARU TANOKURA

17.1 Introduction 149

17.2 Composition of Green Coffee Beans 149

17.3 Caffeine 149

17.4 Trigonelline 150

17.5 Chlorogenic Acids 150

17.6 Organic Acids 150

17.7 Sucrose and Other Reducing Sugars 151

17.8 Polysaccharides 151

17.9 Protein and Amino Acids 159

17.10 Lipids 159

17.11 Minerals 160

17.12 Chemical Composition of Defective Coffee Beans 160 References 161

18. Polysaccharides in Coffee and Their Relationship to Health: An Overview CARMEN L. DE OLIVEIRA PETKOWICZ

18.1 Introduction 163

18.2 Green Coffee 163

18.3 Roasted Coffee 167

18.4 Health Aspects of Coffee Polysaccharides 169

18.5 Summary Points 171

References 171
19. Galactomannans in Coffee

ANA S.P. MOREIRA, FERNANDO M. NUNES, M. ROSÁRIO M. DOMINGUES, MANUEL A. COIMBRA

19.1 Introduction 173

19.2 Structural Features of Green Coffee Galactomannans 174

19.3 Effect of the Roasting Process on the Structure of Coffee Galactomannans 176

19.4 Potential Health Implications of Coffee Polysaccharides 178

19.5 The Effect of Galactomannans on Organoleptic Properties of Coffee Beverages 180

19.6 Summary Points 181 References 181

20. Melanoidins in Coffee JOSÉ A. RUFIÁN-HENARES, SILVIA PASTORIZA

20.1 Introduction 183

20.2 Chemical Composition 183

20.3 Mechanistic Formation and Structure of Coffee Melanoidins 185

20.4 Final Remarks 187

20.5 Summary Points 187

References 188

\section{Chlorogenic Acids from Coffee} YUSAKU NARITA, KUNIYO INOUYE

21.1 Introduction 189

21.2 CGAs in Green Coffee Beans 192

21.3 CGAs in Roasted Coffee Beans 192

21.4 CGAs in Defective Coffee Beans, Spent Coffee Grounds, and Coffee Silverskin 197

21.5 Summary Points 197 References 197

\section{Caffeine in Coffee FRANCISZEK BURDAN}

22.1 Introduction 201

22.2 Content of Caffeine in Coffee and in Nutritional and Medical Products 201

22.3 Caffeine Consumption 205

22.4 Pharmacokinetics of Caffeine 206

22.5 Summary Points 206

References 207

\section{Coffee and Hippuric Acid} MASANORI OGAWA

23.1 Introduction 209

23.2 Metabolism of CGA to HA 209

23.3 Elevation of HA in Human Studies 209

23.4 Variation of Colonic Microflora 210

23.5 Biological Properties of CGA and HA 210

23.6 Other Sources of HA 212 
23.7 Present Status in the Estimation of Toluene Exposure in the Occupational Field 213

23.8 Summary Points 213

References 214

24. Factors Affecting Acrylamide Levels in Coffee Beverages

CRISTINA M.D. SOARES, RITA C. ALVES, M. BEATRIZ P.P. OLIVEIRA

24.1 Introduction 217

24.2 Factors Affecting Acrylamide Levels in Coffee Beverages 217

24.3 Reduction of Acrylamide in Coffee Products 222

24.4 Conclusion 223

24.5 Summary Points 223

Acknowledgments 223

References 223

25. Mycotoxins in Coffee

TIAGO VIEIRA, SARA CUNHA, SUSANA CASAL

25.1 Introduction 225

25.2 What are Mycotoxins? 225

25.3 Major Mycotoxins in Coffee 226

25.4 Coffee Processing and Mycotoxin Contamination 229

25.5 Summary Points 231

Acknowledgments 231

References 231

\section{Pesticide Residues in Coffee} Agroecosystems

MARCELO RODRIGUES DOS REIS, FLÁVIO LEMES FERNANDES, EVERALDO ANTÔNIO LOPES, JÉSSICA EMILIANE RODRIGUES GORRI, FLÁVIA MARIA ALVES

26.1 Introduction 235

26.2 Pesticides (Fungicides, Herbicides, Insecticides, and Nematicides) 235

26.3 New Strategies for Reducing Pesticide Residues in Coffee 243

26.4 Summary Points 243

References 244

\section{Part 1.4 Coffee Types and Coffee Drinking Culture}

27. Physicochemical Characteristics of Roasted Coffee

XIUJU WANG, LOONG-TAK LIM

27.1 Introduction 247

27.2 Physical and Structural Characteristics of Roasted Coffee Beans 247

27.3 Chemical Composition 249

27.4 Summary Points 252

References 253
28. Espresso Machine and Coffee Composition SAURO VITTORI, GIOVANNI CAPRIOLI, MANUELA CORTESE, GIANNI SAGRATINI

28.1 Introduction 255

28.2 Espresso Coffee Machine: Working Principles 256

28.3 Influence of Water Temperature and Water Pressure on ECs Quality 257

28.4 Time Portions: Extraction Kinetic 259

28.5 Conclusions 262

28.6 Summary Points 263

References 263

29. Boiled Coffee: An Arctic Example of Potential Residual and Unmeasured Confounding in Coffee Epidemiology

LENA MARIA NILSSON

29.1 Introduction 265

29.2 Residual and Unmeasured Confounding in Coffee Epidemiology 265

29.3 Coffee: A Part of the Scandinavian Culture Since the 1700s 266

29.4 Chemical Implications of the Preparation of Boiled Coffee 267

29.5 Risk Associations in Boiled and Filtered Coffee 268

29.6 Lifestyle Factors Associated with Consumption of Boiled and Filtered Coffee 268

29.7 Discussion 272

29.8 Summary Points 273

References 273

30. Personality Traits and Coffee Intake DIOGO R. LARA

30.1 Introduction 275

30.2 Personality Traits Associated with Coffee and Caffeine Intake 276

30.3 Differential Response to Caffeine According to Personality Traits and Psychiatric Disorders 276

30.4 Chronic Use of Coffee, Personality Traits, and Psychiatric Disorders 277

30.5 Conclusions 278

30.6 Summary Points 278

References 279

\section{Part 1.5 By-Products and Secondary Usage}

31. An Overview of the Potential Uses for Coffee Husks

LEANDRO S. OLIVEIRA, ADRIANA S. FRANCA

31.1 Introduction 283

31.2 Coffee Processing 283 
31.3 Chemical Composition of CHs and CP 285

31.4 Review of Proposals for the Profitable Exploitation of $\mathrm{CHs}$ and CP 286

31.5 Concluding Remarks 290

31.6 Summary Points 290 Acknowledgments 290 References 290

32. Use of Coffee Husk Waste for Production of Biopesticides for Mosquito Control

SUBBIAH POOPATHI, C. MANI

32.1 Introduction 293

32.2 Method of Biopesticide Production from CHW 294

32.3 Salient Features of the Study 296

32.4 Conclusion 299

32.5 Summary Points 299

Acknowledgments 299

References 300

33. Production of Selenium-Enriched Mushrooms in Coffee Husks and Use of This Colonized Residue

MARIA CATARINA MEGUMI KASUYA, JOSÉ MARIA RODRIGUES DA LUZ, MATEUS DIAS NUNES, MARLIANE DE CÁSSIA SOARES DA SILVA, DANIELE RUELA DE CARVALHO, LAÉLIA SOARES DE ASSUNÇÃO, THIAGO DE ALMEIDA PAULA, CAROLINE MOURA, CLÁUDIA BRAGA PEREIRA BENTO

33.1 Introduction 301

33.2 Production of Different Types of Mushrooms 302

33.3 Enrichment of Mushrooms with Selenium 303

33.4 Potential Use of the Coffee Husk in Animal Feed after Fungal Colonization 305

33.5 Conclusions/Summary Points 307 Acknowledgments 308 References 308

34. Spent Coffee-Based Activated Carbons: Production, Properties, and Environmental Applications TERESA J. BANDOSZ, KARIFALA KANTE

34.1 Introduction 311

34.2 Preparation of Coffee-Based Activated Carbons and Their Surface Features 312

34.3 Applications as Adsorbents from Gas and Vapor Phases 314

34.4 Applications of Coffee-Derived Carbons as Adsorbents from Liquid Phase 314

34.5 Applications of Coffee-Derived Carbons as Supercapacitors 315

34.6 Summary Points 316

References 317
SECTION 2

EFFECTS OF COFFEE CONSUMPTION

\section{Part 2.1 Infection and Immunity}

35. Coffee Consumption and C-reactive Protein: Epidemiological Studies

NGOC M. PHAM, VICTOR R. PREEDY

35.1 Introduction 323

35.2 Epidemiological Evidence for the Relationship between Coffee and CRP 325

35.3 Interpreting and Analyzing the Data on the Relationship between Coffee and CRP 329

35.4 Conclusions 332

35.5 Summary Points 332

References 332

36. Effects of Coffee on Antigen-Specific Immune Responses In Vivo and In Vitro MASAO GOTO, YUKO TAKANO-ISHIKAWA

36.1 Introduction 335

36.2 Effects of Coffee Administration in a DO11.10 Allergic Mouse Model 336

36.3 Change in Antigen-Specific Proliferation of Splenocytes Caused by Drinking Coffee 340

36.4 Summary Points 341

References 342

37. Anti-Hepatitis C Virus Treatment and Coffee Drinking ALEXANDRE PARIENTE, RODOLPHE ANTY

37.1 Factual Associations 343

37.2 Coffee Drinking and Liver Lesions in Hepatitis C 343

37.3 Coffee Drinking and Response to Treatment with Peginterferon and Ribavirin 345

37.4 An Interventional Study of Coffee in Hepatitis C 346

37.5 Conclusion 346 References 346

\section{Part 2.2 Cancer}

38. Epidemiological Evidence on the Relation between Coffee Intake and the Risk of Head and Neck Cancer ALESSANDRA TAVANI, CARLOTTA GALEONE, FEDERICA TURATI, LODOVICA CAVALLI, CARLO LA VECCHIA

38.1 Introduction 349

38.2 Main Text 349 
38.3 Summary Points 357

Acknowledgments 357

References 357

39. Coffee Consumption and Prostate Cancer VAN DONG HOANG, VAN DINH TRAN, ANDY H. LEE

39.1 Introduction 359

39.2 Literature Search 360

39.3 Epidemiological Evidence (Before 2000) 360

39.4 Epidemiological Evidence (2001-Present) 363

39.5 Limitations 364

39.6 Conclusions and Future Perspectives 365

39.7 Summary Points 365

References 365

40. Coffee Intake and Pancreatic Cancer Risk JEANINE M. GENKINGER, VALERIE GEBARA

40.1 Introduction 367

40.2 Coffee Consumption and Carcinogenesis 367

40.3 Pancreatic Cancer Epidemiology 367

40.4 Pancreatic Cancer Risk Factors 368

40.5 Coffee Intake and Pancreatic Cancer Risk in Epidemiologic Studies 368

40.6 Summary 372

40.7 Summary Points 372

References 372

\section{Part 2.3 Cardiovascular}

41. Coffee and Risk of Cardiovascular Disease:

An Overview of Epidemiologic Studies ROMINA DI GIUSEPPE, JANINE WIRTH, CORNELIA WEIKERT

41.1 Introduction 377

41.2 Coffee and CHD Risk 377

41.3 Coffee and Stroke Risk 380

41.4 Coffee and Heart Failure Risk 382

41.5 Coffee and CVD Mortality 383

41.6 Concluding Remarks 383

41.7 Summary Points 384

Acknowledgments 384

References 384

42. Coffee Polyphenols and High Cardiovascular Risk

\section{Parameters}

ANNA TRESSERRA-RIMBAU, ALEXANDER MEDINA-REMÓN, RAMON ESTRUCH, ROSA M. LAMUELA-RAVENTÓS

42.1 Introduction 387

42.2 Coffee: An Important Source of

Polyphenols 387

42.3 Bioavailability of Coffee Polyphenols 388
42.4 In Vitro and Human Cell Studies 389

42.5 Animal Studies 390

42.6 Epidemiological Studies 390

42.7 Clinical Trials 391

42.8 Summary Points 393

References 393

43. Coffee and Hypertension: A Focus on Contrasting Acute and Chronic Effects and

Nutrigenetics

GIULIA RENDA, RAFFAELE DE CATERINA

43.1 Introduction 395

43.2 Acute Effects of Coffee on Blood Pressure 396

43.3 Effects of Coffee on the Long-term Risk of Hypertension 397

43.4 Nutrigenetics of Blood Pressure Responses to Coffee Drinking 399

43.5 Conclusions 400

43.6 Summary Points 400

References 401

44. Coffee Consumption and Risk of Venous Thromboembolism

KRISTIN F. ENGA, JOHN-BJARNE HANSEN

44.1 Clinical Presentation 403

44.2 Incidence and Complications 403

44.3 Pathogenesis and Risk Factors 403

44.4 Coffee Consumption and Risk of VTE 405

44.5 Underlying Protective Mechanisms of Coffee on Risk of VTE 406

44.6 Limitations of Findings on Behavioral Factors in Observational Studies 407

44.7 Conclusions 407

44.8 Summary Points 407

References 407

45. Coffee Consumption and Serum Lipids: A Review of Epidemiological Studies and Experimental Studies in Humans

DEFU MA, LI CAI, XIAOLONG HAN, PEIYU WANG

45.1 Introduction 409

45.2 Epidemiological Studies on Coffee Consumption and Serum Lipids 409

45.3 Experimental Studies on Coffee Consumption and Serum Lipids 410

45.4 Boiled Coffee and Filter Coffee 411

45.5 Caffeinated Coffee and Decaffeinated Coffee 418

45.6 Conclusions 419

45.7 Summary Points 419

References 419 


\section{Part 2.4 Nervous System and Behaviour}

46. Coffee and its Active Compounds are

Neuroprotective

JIYOUNG KIM, KI WON LEE

46.1 Introduction 423

46.2 Caffeine as a Neuroprotectant 423

46.3 Decaffeinated Coffee Is Neuroprotective 423

46.4 Neuroprotective Active Compounds in Coffee 424

46.5 Antioxidative Activities of Phytochemicals in Coffee 425

46.6 Anti-inflammatory Activities of Phytochemicals in Coffee 425

46.7 Conclusion 426

46.8 Summary Points 426

Acknowledgments 426

References 426

47. Coffee and Amyotrophic Lateral Sclerosis

GIORGIA GIUSSANI, ELISABETTA PUPILLO, PAOLO MESSINA, ETTORE BEGH

47.1 Introduction: The Disease 429

47.2 Coffee and ALS: The Epidemiological

Evidence 429

47.3 Molecular Targets of Caffeine in the Central Nervous System 431

47.4 Studies in Animal Models 431

47.5 Electrophysiological Effects of Caffeine 432

47.6 Caffeine and Other Neurodegenerative Disorders 432

47.7 Effects of Other Constituents of Coffee 433

47.8 Summary Points 433

References 433

48. Coffee, Granulocyte Colony-Stimulating Factor (G-CSF), and Neurodegenerative

Diseases

CHUANHAI CAO, THEA MOORE, LI CHU, OING XU

48.1 Background 435

48.2 Coffee, Caffeine, and AD and Parkinson's

Disease 437

48.3 Coffee and G-CSF 440

48.4 The Mechanism of Coffee Benefit in Neurodegenerative Disease 440

48.5 Conclusions 441

48.6 Summary Points 441

Acknowledgments 441

References 441
49. Coffee-Induced Neural Tube Defects

GIANFRANCO CARLOMAGNO, SARA DE GRAZIA, ALBERTO VAIARELLI, VITTORIO UNFER

49.1 Introduction 443

49.2 NTDs, Folic Acid, and Inositol 444

49.3 Caffeine Intake and NTDs 445

49.4 Summary Points 447

References 447

50. Coffee and Anxiety

CONCEPCIÓN VINADER-CAEROLS, SANTIAGO MONLEÓN, ANDRÉS PARRA

50.1 Introduction 449

50.2 What Is Anxiety? 449

50.3 Coffee and Normal Anxiety 450

50.4 Coffee and Pathological Anxiety 452

50.5 Conclusions 453

50.6 Summary Points 454

Acknowledgments 454

References 454

51. Coffee-Related Insomnia

JENNIFER COUSINS, IRIS R. BELL, RICHARD R. BOOTZIN

51.1 Introduction 457

References 463

\section{Part 2.5 Diabetes and Glucose Control}

52. Coffee Intake and Diabetes

TERESA H.M. DA COSTA, CAIO E.G. REIS, ADRIANA LOFRANO PORTO, ANGÉLICA AMATO, JOSÉ G. DOREA

52.1 Introduction 467

52.2 Prospective Longitudinal Cohort Studies of Coffee and Type 2 Diabetes 467

52.3 Cross-sectional Studies of Coffee and Type 2 Diabetes 474

52.4 Summary Points 477

References 477

53. The Influence of Acute Caffeine and Coffee Consumption on Glucose Homeostasis: Whole-Body and Tissue-Specific Effects and Mechanisms of Actions MARIE-SOLEIL BEAUDOIN, TERRY E. GRAHAM

53.1 Introduction 479

53.2 Acute Effects of Alkaloid Caffeine on Glucose Homeostasis 479 
53.3 Acute Effects of Caffeinated Coffee on Carbohydrate Homeostasis 481

53.4 Considerations in Caffeine/Coffee-Induced Insulin Resistance 484

53.5 Proposed Mechanisms of Action for Caffeine 484

53.6 Conclusion 487

53.7 Summary Points 488

References 488

\section{Part 2.6 Metabolism and Other Organ Systems}

54. Coffee Consumption and Neglected Risk-Benefits on Health and Disease

ELENA ALONZO, FRANCESCA M. TROVATO, DANIELA CATALANO, GUGLIELMO M. TROVATO

54.1 Introduction 493

54.2 Surgical and Anesthesia-Related

Conditions 493

54.3 Pregnancy, Fertility, and Sexual-Related Ailments 494

54.4 Menopause 494

54.5 Childbearing and Infancy 495

54.6 Infectious Disease 495

54.7 Respiratory Disease (Asthma and COPD) 495

54.8 Dentistry 495

54.9 Occupational Disease 495

54.10 Conclusions 495

54.11 Summary Points 495

References 496

55. Coffee Consumption and Body Weight

Regulation

MARIE-PIERRE ST-ONGE

55.1 Introduction 499

55.2 Epidemiological Evidence Linking Coffee Consumption and Weight Status 499

55.3 Impact of Coffee and Caffeine on EE 501

55.4 Effects of Coffee Consumption on Appetite Regulation 502

55.5 Effects of Coffee Consumption in Weight Loss 503

55.6 Summary Points 505

References 505

56. Coffee Consumption and Adiponectin: An Overview of Epidemiological Studies

\section{TAKUYA IMATOH}

56.1 Introduction 507

56.2 Adiponectin 508

56.3 Published Epidemiological Studies on Association between Coffee Consumption and Adiponectin Level 510

56.4 Potential Mechanisms that Increase the Levels of Adiponectin 510
56.5 Which Coffee Components Play an Important Role on Increasing Adiponectin Levels? 512

56.6 Discussion 513

56.7 Summary Points 514

References 514

57. Effect of Coffee Consumption on Oral Health

FLÁVIO HENRIQUE BAGGIO AGUIAR, NÚBIA PAVESI PINI, DÉBORA ALVES NUNES LEITE LIMA, JOSÉ ROBERTO LOVADINO

57.1 Introduction 517

57.2 Review of Literature 517

57.3 Summary and Conclusions 520

57.4 Summary Points 520

References 520

58. Role of Coffea arabica Extract and Related Compounds in Preventing Photoaging and Photodamage of the Skin

HSIU-MEI CHIANG, CHIEN-WEN CHEN, CHIEN-CHIA CHEN, HSIAO-WEN WANG, JHE-HUA JHANG, YA-HAN HUANG, KUO-CHING WEN

58.1 Introduction 523

58.2 Aging and Photoaging 523

58.3 Mechanisms of Photoaging 524

58.4 Antioxidant Activity of Coffee 525

58.5 Coffee Prevents Skin Photoaging 525

58.6 Coffee Prevents Skin Tumor Formation 526

58.7 Effect of Coffee Constituents on Photoaging and Photocarcinogenesis 526

58.8 Conclusion 529

58.9 Summary Points 529

References 529

59. Coffee and Renal Function and Disease DANIELA CATALANO, FRANCESCA M. TROVATO, FABIO MARTINES, GUGLIELMO M. TROVATO

59.1 Introduction 531

59.2 Conclusion 534

References 534

60. Coffee and Gastrointestinal Glucuronosyltransferases CHRISTIAN P. STRASSBURG, SANDRA KALTHOFF

60.1 Introduction 535

60.2 UDP-Glucuronosyltransferases 535

60.3 Glucuronidation of Hydroxycinnamic Acids 537

60.4 Coffee-Mediated UGT1A Regulation in Cell Culture 537

60.5 Coffee-Mediated UGT1A Activation in Mouse Models 539

60.6 Contribution of UGTs to the Coffee-Mediated Protective Effects on the Metabolism and Genotoxicity of the Dietary Carcinogen PhIP 540

60.7 Summary Points 542 References 542 
61. Effects of Coffee on Estrogen Sulfation in Human Colon Carcinoma Caco-2 Cells HIROOMI TAMURA

61.1 Introduction 545

61.2 Coffee Inhibits Sulfation of Estradiol in Caco-2 Cells 546

61.3 Characterization of the Inhibitory Activity in Coffee Toward $E_{2}$ Sulfation in Caco-2 Cells 546

61.4 Effects of Coffee on the Expression of SULT1E1 547

61.5 Effects of Coffee on STS and BCRP 547

61.6 Characterization of the Active Constituents that Regulate the Expression of the Estrogen SulfationRelated Genes SULT1E1, STS, and BCRP 549

61.7 Conclusion 551

61.8 Summary Points 551

Acknowledgments 551

References 551

62. Coffee and the Liver: An Overview of Epidemiologic Studies RODOLPHE ANTY, ALEXANDRE PARIENTE

62.1 Summary Points 553

62.2 The Limits of Epidemiological Studies 553

62.3 Coffee and Liver Enzymes 554

62.4 Coffee, Cirrhosis, and Liver Fibrosis 554

62.5 Coffee, NAFLD, and NASH 556

62.6 Coffee and Hepatocellular Carcinoma 556

62.7 Putative Mechanisms of Action of Coffee on the Liver 557

62.8 Conclusions 557

Acknowledgment 557

References 557

63. Organic and Conventional Arabica Coffee L: Protective Effects on Liver Under Pre-neoplastic Conditions

CRISTIANA SCHMIDT DE MAGALHÃES, LUCIANA AZEVEDO, JESSICA EMI TAKARADA, NATHÁLIA CARVALHO COSTA, DAYENE DO CARMO CARVALHO

63.1 Introduction 559

63.2 Differentiation in Coffee Production System 560

63.3 Coffee Compounds 561

63.4 Liver Neoplasia 562

63.5 Coffee: Bioprotector Effect in Liver Neoplasia 562

63.6 Conclusion 565

63.7 Summary Points 565

References 565

64. Coffee and Prevention of Nonalcoholic Fatty Liver Disease

FRANCESCA M. TROVATO, DANIELA CATALANO, GIUSEPPE F. MARTINES, GUGLIELMO M. TROVATO

64.1 Introduction 567

64.2 Coffee and NAFLD 568
64.3 Summary Points 572

References 572

65. Estimate of Acrylamide Intake from Coffee and Health Risk Assessment ADRIANA PAVESI ARISSETO, EDUARDO VICENTE

65.1 Introduction 575

65.2 Toxicological Aspects of Acrylamide 576

65.3 Exposure Assessment to Acrylamide from Coffee 577

65.4 Health Risk Assessment 581

65.5 Cancer Evidence from Epidemiological Studies 582

65.6 Considerations about Risk Management

Actions 582

65.7 Conclusions 582

65.8 Summary Points 583

References 583

\section{Part 2.7 Cellular and Molecular Biology}

66. Protective Effects of Coffee Against Induction of DNA Damage and Cancer by Aflatoxin $B_{1}$

FRANZISKA FERK, KARL SPEER, MIROSLAV MIŠÍK, ARMEN NERSESYAN, SIEGFRIED KNASMÜLLER

66.1 Introduction 587

66.2 Occurrence of Aflatoxins in Foods and Human Cancer

Risks Caused by Consumption of Contaminated

Foods 587

66.3 Metabolism and Detoxification of $\mathrm{AFB}_{1} \quad 588$

66.4 Prevention of DNA Damage and Inhibition of Preneoplastic Lesions 588

66.5 Prevention of DNA Damage by Different Constituents of Coffee 588

66.6 Molecular Mechanisms 591

66.7 Does Coffee Protect Humans against Aflatoxin $B_{1}$ ? 593

66.8 Summary Points 594

References 594

67. Instant Coffee and Protection against DNA

Damage

TAKESHI HIRANO, HARUKI MORII, TAMIJI NAKASHIMA

67.1 Introduction 597

67.2 Coffee Consumption and Cancer 597

67.3 8-Oxoguanine 598

67.4 8-Oxoguanine Repair System 599

67.5 Instant Coffee Consumption and 8-Oxoguanine Generation and Repair 599

67.6 Conclusions 601

67.7 Summary Points 601

Acknowledgments 601

References 601 


\section{SECTION 3}

\section{EFFECTS OF SPECIFIC COMPOUNDS FOUND IN COFFEE}

\section{Part 3.1 Infection and Immunity}

68. Anti-Hepatitis B Virus Activity of Chlorogenic Acid and Its Related Compounds JIANPING ZUO, WEI TANG, YIBIN XU

68.1 Anti-Hepatitis B Virus Activity of Chlorogenic Acid and Its Related Compounds 607

68.2 Chlorogenic Acid Possesses Potent Anti-HBV Activity 608

68.3 Anti-HBV Activity of Chlorogenic Acid-Related Compounds 609

68.4 Hybrids of Caudatin and Chlorogenic Acid 610

68.5 Summary Points 612

References 612

69. Coffea canephora: A Promising Natural Anticariogenic Product

DANIEL COHEN GOLDEMBERG, ANDREA GONÇALVES ANTONIO, ADRIANA FARAH, LUCIANNE COPLE MAIA

69.1 Introduction 615

69.2 Coffea canephora 616

69.3 Dental Caries Pathogenesis and the Protective Role of Coffee: A Focus on C. canephora Species 617

69.4 Conclusions 623

69.5 Summary Points 624

Acknowledgments 624

References 624

70. Kahweol, a Coffee Diterpene with Anti-inflammatory Properties

CASIMIRO CÁRDENAS, ANA R. QUESADA, MIGUEL Á. MEDINA

70.1 Introduction 627

70.2 Kahweol Modulates Nitric Oxide Synthesis 627

70.3 Kahweol Modulates Cyclooxygenase-2 Expression 628

70.4 Kahweol Modulates Cell Adhesion 629

70.5 Kahweol Protects against Oxidative Stress and DNA Damage 629

70.6 Kahweol Targets NF-кB/STAT-1-Mediated Inflammatory Responses 630

70.7 Kahweol Targets MCP-1 Secretion in Endothelial Cells 630

70.8 Kahweol Behaves as an Anti-Angiogenic Agent 630

70.9 Concluding Remarks 631

70.10 Summary Points 632

References 632
71. Antifungal Inhibitory Activities of Caffeic and Quinic Acid Derivatives

JAN-NAN MA, CHAO-MEI MA

71.1 Introduction 635

71.2 Caffeoylquinic, Caffeic, and Quinic Acid Derivatives with Antifungal Activity 637

71.3 Summary Points 640 Acknowledgment 641 References 641

\section{Part 3.2 Cancer}

72. On the Linkage between Caffeine, Cytokine Secretion, and Cancer

MEIR DJALDETTI, MICHAEL BERGMAN, HERTZEL SALMAN, HANNA BESSLER

72.1 Introduction 645

72.2 Caffeine, Cytokine Secretion, and Cancer 645

72.3 Summary Points 652

References 652

73. Anticancer Effect of Caffeic Acid on Human Cervical Cancer Cells

G. KANIMOZHI, N.R. PRASAD

73.1 Introduction 655

73.2 Caffeic Acid on Cancer Cell Proliferation 656

73.3 Caffeic Acid on Intracellular ROS Level, Mitochondrial Membrane Potential, and Apoptosis 656

73.4 Changes in the Levels of Lipid Peroxidative and the Activities of Enzymatic Antioxidants 658

References 660

74. Caffeic and Ferulic Acid Derivatives: Use in Breast Cancer

TERESA L. SERAFIM, NUNO MILHAZES, FERNANDA BORGES, PAULO J. OLIVEIRA

74.1 Introduction: Coffee Consumption and Breast Cancer 663

74.2 Caffeic and Ferulic Acid Antibreast Cancer Activity 665

74.3 Summary Points 669

References 670

75. Molecular Targets of Coffee Phytochemicals Caffeic Acid and Chlorogenic Acid in

Chemoprevention ANN M. BODE, ZIGANG DONG

75.1 Introduction 673

75.2 Antioxidant Activity of Coffee and Its Components 674

75.3 Strategies for Identifying Molecular Targets of Coffee Components 676

75.4 Summary Points 678

References 678 


\section{Part 3.3 Cardiovascular}

76. Caffeine and SPECT Myocardial Perfusion Imaging

FURQAN H. TEJANI, SARITA KONKA

76.1 Introduction 683

76.2 Coronary Artery Disease 683

76.3 TIMI Risk Score 683

76.4 Myocardial Ischemia 683

76.5 Principle of Cardiac Stress Testing 684

76.6 Types of Cardiac Stress Tests 684

76.7 Sensitivity/Specificity of Cardiac Stress Testing 684

76.8 Effects of Caffeine on Stress Testing 684

76.9 Current Guidelines Regarding Caffeine and Stress Testing 688

76.10 Topics to Consider and Future Investigations 688

76.11 Summary Points 688

References 688

\section{Caffeine and Atrial Fibrillation ANNA VITTORIA MATTIOLI}

77.1 Introduction 691

77.2 Pathophysiological Link between Caffeine and Arrhythmias 691

77.3 Human Studies 693

77.4 Energy Drinks and Caffeine 695

77.5 Conclusions 697

77.6 Summary Points 697

References 697

78. Caffeine Cardiovascular Toxicity: Too Much of a Good Thing CLÁUDIA DEUS, ANA F. BRANCO, PAULO J. OLIVEIRA, VILMA SARDÃO

78.1 Introduction 699

78.2 Caffeine and the Heart 699

78.3 Summary Points 706

References 707

79. Potential Effects of Chlorogenic Acids on Platelet Activation

JAE B. PARK

79.1 Introduction 709

79.2 Coffee and Its Chemicals 709

79.3 Chemical Properties, Absorption, and Metabolism of CHAs 710

79.4 Bioavailability of Chlorogenic Acids 711

79.5 Cardiovascular Disease and Chlorogenic Acids 712

79.6 Effects of Chlorogenic Acids on ROS 713

79.7 Effects of Chlorogenic Acids on COX-I and II Enzymes 714

79.8 Effects of Chlorogenic Acids on P-Selectin 714

79.9 Conclusion 715

References 715

\section{Part 3.4 Nervous System and Behaviour}

80. Use of Caffeine for Cognitive Enhancement ANDREAS G. FRANKE, CHRISTIANA BAGUSAT

80.1 Introduction 721

80.2 Mechanism of Action 722

80.3 Cognitive-Enhancing Effects and Side Effects of Caffeine 723

80.4 Epidemiology of the Use of Caffeine for CE 724

80.5 Conclusions 726

80.6 Summary Points 726

References 726

81. Caffeolyquinic Acid Protects against Alzheimer's Disease through Inhibition of Amyloid Beta-Induced Toxicity

JUNKYU HAN, ABDELFATTEH EL OMRI, KAZUNORI SASAKI, HIROKO ISODA

81.1 Introduction 729

81.2 Caffeolyquinic Acid 729

81.3 Amyloid $\beta 731$

81.4 Neuroprotective Effect of CQA 731

81.5 Protective Effect on the Aggregation of $A \beta 732$

81.6 Conclusion 733

81.7 Summary Points 733

References 734

82. Neuroactive $\beta$-Carbolines Norharman and Harman in Coffee SUSANA CASAL

82.1 Introduction 737

82.2 Norharman and Harman: The Molecules 737

82.3 Norharman and Harman Health Impact 738

82.4 Norharman and Harman in Coffee 740

82.5 Summary Points 742

References 742

\section{Part 3.5 Diabetes and Glucose Control}

\section{Caffeine, Insulin Resistance,} and Hypertension

MARIA PEDRO GUARINO, JOANA SACRAMENTO, MARIA JOÃO RIBEIRO, SÍLVIA VILARES CONDE

83.1 Caffeine and the Metabolic Syndrome 747

83.2 Caffeine-Pharmacology and Mechanisms of Action 748

83.3 Effect of Caffeine on Insulin Action 749

83.4 Caffeine and Hypertension 750

83.5 Chronic Caffeine Administration in the Prevention and Reversion of Diet-Induced Insulin Resistance and Hypertension 751 
83.6 The Carotid Body as a Pharmacological Target for Caffeine 753

83.7 Summary Points 753

References 754

84. Inhibition of Porcine Pancreas $\alpha$-Amylase by Chlorogenic Acids from Green Coffee Beans and Cinnamic Acid Derivatives: A Focus on Kinetic YUSAKU NARITA, KUNIYO INOUYE

84.1 Introduction 757

84.2 PPA Inhibitory Effects of 5-CQA, CA, and QA 758

84.3 PPA Inhibition by Eight Types of CGAs and Cinnamate Derivatives 761

84.4 Summary Points 762

References 762

85. Antidiabetic Effects of Trigonelline: Comparison with Nicotinic Acid

ORIE YOSHINARI, KIHARU IGARASHI

85.1 Introduction 765

85.2 The Effects of TRG and NA on T2DM Using GotoKakizaki Rats as a Nonobese Animal Model 766

85.3 How Does TRG Ameliorates Oxidative Stress in GK Rats? 766

85.4 The Antidiabetic Effect of TRG and NA on T2DM

Using KK-Ay Mice as an Obese Animal Model 769

85.5 Summary 773

85.6 Summary Points 774

References 774

86. Chlorogenic Acid in Whole Body and Tissue-Specific Glucose Regulation JASMINE M. TUNNICLIFFE, THERESA COWAN, JANE SHEARER

86.1 Introduction 777

86.2 Chlorogenic Acid 777

86.3 Content in Coffee 778

86.4 Chlorogenic Acid Absorption 778

86.5 CGA in Blood Glucose Management 779

86.6 Summary Points 783

References 784

\section{Part 3.6 Metabolism and Other Organ Systems}

87. Bioavailability and Metabolism of Chlorogenic Acids from Coffee

ADRIANA FARAH, GISELLE DUARTE

87.1 Introduction 789

87.2 CGA Content in Green Coffee 791

87.3 CGA in Ground Roasted and Brewed Coffees and Human Daily Intake 791
87.4 Bioavailability and Metabolism of CGA from Coffee 792

87.5 Interaction between CGA and Other Food Components 799

87.6 Concluding Remarks 800

87.7 Summary Points 800

References 800

88. Inhibitory Effects of Caffeic Acid on Free-Radical Formation HIDEO IWAHASHI

88.1 Introduction 803

88.2 Summary Points 810

References 810

89. Effects of Caffeic, Ferulic, and p-Coumaric Acids on Lipid Membranes NATAŠA POKLAR ULRIH

89.1 Introduction 813

89.2 Interactions of Hydroxycinnamic Acids with Model Lipid Membranes 814

89.3 Effects of Phenolic Acids on the Rigidity of Model Membranes in the Liquid-Disordered State 814

89.4 Effects of Phenolic Acids on the Rigidity of Model Membranes in the Gel Crystalline State 814

89.5 Correlation between Phenolic-Acid Polarity and Influence on the Properties of Model Lipid Membranes 815

89.6 Caco-2 Cell Permeation 817

89.7 Transcellular Permeability Model 817

89.8 Facilitated Mechanisms of Transport of Phenolic Acids through the Colon Epithelium 818

89.9 Interactions of p-Coumaric Acid with Lysosomes 818 89.10 The Blood-Brain Barrier 819

89.11 Summary Points 819

References 820

90. Pharmacology of Caffeine: The Main Active Compound of Coffee FRANCISZEK BURDAN

90.1 Introduction 823

90.2 Pharmacokinetics of Caffeine 823

90.3 Pharmacodynamics of Caffeine 827

90.4 Summary Points 828

References 828

91. Adenosine Receptors as the Biochemical Target for Low Doses of Caffeine B.B. FREDHOLM

91.1 Introduction 831

91.2 Caffeine Levels and Antagonism of Adenosine Receptors 831

91.3 Adenosine Levels and Activation of Adenosine Receptors 832 
91.4 Validation of Adenosine Receptors as a Major Caffeine Target 833

91.5 Summary Points 833

References 833

92. Antioxidant Activity of Caffeine: A Focus on Human Red Blood Cells and Correlations with Several Neurodegenerative Disorders ESTER TELLONE, ANTONIO GALTIERI, BRUNO GIARDINA, ANNAMARIA RUSSO, ERSILIA BELLOCCO, DAVIDE BARRECA, SILVANA FICARRA

92.1 Introduction 835

92.2 Oxygen and Its Toxicity 835

92.3 Antioxidant Effects of Caffeine 836

92.4 Summary Points 841

References 841

93. Antioxidant Properties of Hydroxycinnamic Acid Derivatives: A Focus on Biochemistry, Physicochemical Parameters, Reactive Species, and Biomolecular Interactions HELENA ABRAMOVIČ

93.1 Introduction 843

93.2 Efficiency of HCs to Scavenge Reactive Nitrogen or Oxygen Species 845

93.3 Effect of HCs on the Oxidation of Biomolecules 847

93.4 Summary Points 850

References 851

94. Biological Effects of Coffee Melanoidins JOSÉ A. RUFIÁN-HENARES, SILVIA PASTORIZA

94.1 Introduction 853

94.2 Role of Coffee Melanoidins as Modulators of the Gut Microbiota 854

94.3 Coffee Melanoidins as Antimicrobial Agents 854

94.4 The Antioxidant Activity of Coffee Melanoidins 855

94.5 The Chelating Activity of Coffee Melanoidins 856

94.6 Coffee Melanoidins as Enzymes Modulators 856

94.7 Final Remarks 857

94.8 Summary Points 857 References 858

95. Melanoidins from Coffee and Lipid Peroxidation DAVIDE TAGLIAZUCCHI

95.1 Introduction 859

95.2 Lipid Peroxidation and Diseases 859

95.3 Sources of Dietary Lipid Oxidation Products and ALEs 860

95.4 Coffee Melanoidins: Structure and Biological Activity 861

95.5 Coffee Melanoidins As Radical Scavengers, Metal Chelators, and Lipid Peroxidation Inhibitors 861

95.6 Coffee Melanoidins Inhibit Lipid Peroxidation during Simulated Digestion of Meat 864

95.7 In vivo Evidence of Coffee Melanoidins As Inhibitors of Lipid Peroxidation 865
95.8 Conclusion 866

95.9 Summary Points 866

References 866

96. Coffee and Bone Metabolism: Kahweol and Osteoclastogenesis

EIKO SAKAI, TAKAYUKI TSUKUBA

96.1 Introduction 869

96.2 Kahweol Suppresses OCL Differentiation but Not Cell Viability 870

96.3 Kahweol Has Inhibitory Effects on Intracellular Signaling in OCLs 871

96.4 Kahweol Inhibits the Expression of OCL-Marker Proteins 871

96.5 Kahweol Induces mRNA Expression of Phase II Antioxidative Enzymes in OCLs 872

96.6 Kahweol Enhances HO-1 Protein Expression and Inhibits High Mobility Group Box 1

Release 872

96.7 Conclusion and Perspective 873

96.8 Summary Points 874

References 874

97. The Chemistry of Coffee Furans and Hydroxycinnamates under Simulated Gastric Conditions: Implications for Bioactivity and Bioavailability

ALESSANDRA NAPOLITANO, LUCIA PANZELLA

97.1 Modeling Gastric Conditions 877

97.2 The Acid-Mediated Chemistry of Nitrite in the Stomach 878

97.3 The Role of Thiocyanate and Other Saliva Ingredients 878

97.4 Reactivity of Hydroxycinnamic Acids and Their Esters Toward Acidic Nitrite 878

97.5 Purification and Differential Reaction Behavior of the Furan Diterpenes Cafestol and Kahweol Toward Nitrosating Agents 880

97.6 Implications for the Bioactivity and Bioavailability 883

97.7 Toxicological Implications of the Nitrite-Modified Molecules 884

97.8 Conclusions and Perspectives 884

97.9 Summary Points 885

References 885

98. Furan in Coffee Products: A Probabilistic Exposure Estimation DIRK W. LACHENMEIER

98.1 Introduction 887

98.2 Content of Furan in Coffee 887

98.3 Exposure Estimation 889

98.4 Risk Assessment of Furan in Coffee Products 891

98.5 Summary Points 892

Acknowledgment 892

References 892 


\section{Part 3.7 Cellular and Molecular Biology}

99. Caffeolyquinic Acid Induces the Upregulation of Glycolytic Enzymes

JUNKYU HAN, KAZUNORI SASAKI, ABDELFATTEH EL OMRI, HIROKO ISODA

99.1 Introduction 897

99.2 The Glycolytic and Nonglycolytic Functions of Glycolysis Enzymes 898

99.3 Relationship between Glycolytic Enzymes and Alzheimer's Disease 898

99.4 Metabolomics 899

99.5 Conclusion 900

99.6 Summary Points 900

References 903

100. Caffeic Acid and Organic Anion Transporters hOAT1 and hOAT3 YUICHI UWAI

100.1 Introduction 905

100.2 Renal Tubular Secretion of Drugs by OATs 906

100.3 Methotrexate-NSAID Interaction, as an Example of a Drug-Drug Interaction at OAT1 and OAT3 907

100.4 Inhibitory Effects of Caffeic Acid on Drug Transport by hOAT1 and hOAT3 908

100.5 Discussion of Interaction between Coffee and Substrates of hOAT1 and/or hOAT3 910

100.6 Summary Points 910

References 911

101. The Cytoprotective Effects of Hydroxycinnamic Acid are Mediated by Its Antioxidant Activity SEONG-GENE LEE

101.1 Introduction 913

101.2 Antioxidant Activity of HCAs 914

101.3 Anti-Inflammatory Activity of HCAs 915

101.4 Anti-Apoptotic Effects of HCAs 917

101.5 Metabolism of HCAs in Coffee 918

101.6 Summary Points 919

Acknowledgments 919

References 919

102. Cytoprotective Effect of Coffee Melanoidins LUIS GOYA, SONIA RAMOS, MARIA ANGELES MARTÍN, FRANCISCO J. MORALES

102.1 Introduction 921

102.2 A Cell Culture Model for the Assessment of the Chemopreventive Potential of Dietary Compounds 923

102.3 Coffee Melanoidins Protect HepG2 Cells against Oxidative Stress Induced by t-BOOH 925

102.4 Conclusion 927

102.5 Summary Points 927

Acknowledgments 928

References 928

\section{SECTION 4}

ANALYSIS AND METHODS

103. Use of Near-Infrared Spectroscopy for Coffee Beans Quality Assessment

RICARDO N.M.J. PÁSCOA, MAFALDA C. SARRAGUÇA, LUÍS M. MAGALHÃES, JOÃO R. SANTOS, ANTÓNIO O.S.S. RANGEL, JOÃO A. LOPES

103.1 Introduction 933

103.2 Summary Points 941

References 941

104. Spectroscopic Methods for Chemometric Identification of Defective and Nondefective Coffees ADRIANA S. FRANCA, LEANDRO S. OLIVEIRA

104.1 Introduction 943

104.2 Brief Overview of Spectroscopic Methods 944

104.3 Brief Overview of Chemometrics 945

104.4 Spectroscopic Methods in Green Coffee Analysis 946

104.5 Spectroscopic Methods in Roasted Coffee Analysis 947

104.6 Concluding Remarks 950

104.7 Summary Points 950

Acknowledgments 950

References 951

105. Overview of Currently Applied Techniques for Detection of Adulterants in Coffee and Potential Use of DNA-Based Methods as Promising New Analytical Tools

EDNA MARIA MORAIS OLIVEIRA, ADRIANA FARAH, OTNIEL FREITAS-SILVA, ANDRESSA MOREIRA DE SOUZA, THIAGO FERREIRA DOS SANTOS, MANUELA CRISTINA P. DE A. SANTIAGO

105.1 Introduction 953

105.2 Microscopic Methods 954

105.3 Spectroscopic Methods 955

105.4 Chromatographic Methods 955

105.5 DNA-Based Methods 957

105.6 Final Considerations 958

105.7 Summary Points 959

References 960

106. Assay of Total Antioxidant Capacity of Coffee: Use of a DNA-Based Biosensor

DIANA CRUZ, M. FÁTIMA BARROSO, RITA C. ALVES, MARÍA BEGOÑA GONZÁLEZ-GARCÍA, MARIA JOÃO RAMALHOSA, ABEL J. DUARTE, M. BEATRIZ P.P. OLIVEIRA, CRISTINA DELERUE-MATOS

106.1 Introduction 963

106.2 Sensors for the TAC Evaluation of Coffee Samples 964

106.3 DNA-Based Biosensors for TAC Assessment 965

106.4 Conclusions 969

106.5 Summary Points 969

Acknowledgments 969

References 969 
107. Determination of Polyphenols and Major Purine Alkaloids in Coffee: An Overview VICTORIA F. SAMANIDOU

107.1 Introduction 971

107.2 Analytical Methods 972

107.3 Chromatographic Techniques 974

107.4 Other Techniques 977

107.5 Conclusions 980

107.6 Summary Points 980

References 980

108. Determination of Caffeine in Coffee Using Low-Pressure Chromatography JOÃO RODRIGO SANTOS, ANTÓNIO O.S.S. RANGEL

108.1 Introduction 983

108.2 Analytical Methods for Determining Caffeine in Coffee 984

108.3 Determining Caffeine in Coffee Using a Low-Pressure Chromatographic Flow Injection System 986

108.4 Summary Points 989

Acknowledgments 990

References 990

109. Assay of Kahweol and Cafestol in Coffee MARTA DE TOLEDO BENASSI, RAFAEL CARLOS ELOY DIAS

109.1 Introduction 993

109.2 Sample Preparation and Extraction Methods 994

109.3 Separation, Identification, and Quantification of Diterpenes 995

109.4 Occurrence of Kahweol and Cafestol in Different Coffea Matrices 998

109.5 Summary Points 1003

References 1003
110. Analysis of Furan in Coffee MARTA MESIAS, FRANCISCO J. MORALES

110.1 Introduction 1005

110.2 Analysis of Furan in Food 1005

110.3 Furan in Coffee 1007

110.4 Summary Points 1011

References 1011

111. Analysis of Acrylamide in Coffee FRANCISCO J. MORALES, MARTA MESIAS

111.1 Introduction 1013

111.2 Methods of Analysis for Acrylamide 1014

111.3 Occurence of Acrylamide in Coffee 1017

111.4 Summary Points 1020

References 1020

112. Analysis of the Mycotoxin Ochratoxin A in Coffee

TIAGO VIEIRA, SARA CUNHA, SUSANA CASAL

112.1 Introduction 1023

112.2 Ochratoxin A 1023

112.3 Sampling and Sample Preparation 1024

112.4 Extraction 1025

112.5 Clean-up 1025

112.6 Detection and Quantification 1026

112.7 Confirmation 1028

112.8 Summary Points 1030

References 1030

\section{Index 1033}




\title{
Analysis of Furan in Coffee
}

\author{
Marta Mesias, Francisco J. Morales \\ Department of Characterisation, Quality and Safety, Institute of Food Science, Technology and Nutrition \\ (ICTAN-CSIC), Spanish National Research Council, Madrid, Spain
}

\section{List of Abbreviations}

CAQ/PDMS Carboxen ${ }^{\mathrm{TM}} /$ polydimethylsiloxane GC-MS Gas chromatography-mass spectrometry

HS-GC-MS Headspace-gas chromatography-mass spectrometry

LOD Limit of detection

LOQ Limit of quantification

PLOT Porous layer open tubular

SIM Selected ion monitoring mode

SPME Solid phase micro extraction

\subsection{INTRODUCTION}

Furan $\left(\mathrm{C}_{4} \mathrm{H}_{4} \mathrm{O}\right.$; CAS-Nr. 110-00-9) is a small, heterocyclic organic compound present in the volatile fraction of many thermally processed foods and drinks. Figure 110.1 describes some chemical and physical features of furan. Furan is a colorless liquid and is lipophilic and highly volatile, with a boiling point of $31^{\circ} \mathrm{C} .{ }^{1}$ High concentrations have been detected in baked and roasted products, as well as in foods subjected to retorting in cans and jars, probably because of volatiles being trapped in food containers. ${ }^{2}$ Furan can be generated from the thermal degradation of carbohydrates in the presence or absence of amino acids, from the thermal degradation of certain amino acids, and from the thermal oxidation of ascorbic acid, polyunsaturated fatty acids, or carotenoids. ${ }^{3}$

The occurrence of furan is related to the flavor of food products, providing pleasant characteristics. However,

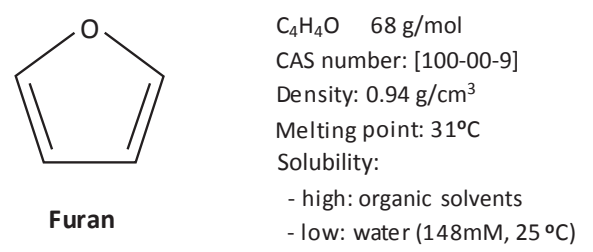

FIGURE 110.1 Chemical structure and physical properties of furan. it also has been associated with toxic and genotoxic effects, and therefore exposure to furan is a human health concern. It is hypothesized that furan induces carcinogenicity through the metabolic activation of cytochrome P450 to cis-2-butene-1,2-diol. Carcinogenic and cytotoxic properties have been evidenced in animals used for experimental testing, and furan has been classified as possibly carcinogenic to humans (group 2B) by the International Agency for Research on Cancer. ${ }^{4}$ For this reason, in recent years this compound has received special attention from food safety agencies, and data on furan concentrations in commercial food products have been collected. In addition, technological strategies aimed at preventing or mitigating furan formation in foods, as well as removing the already formed furan from food products, have been performed. ${ }^{5-7}$

\subsection{ANALYSIS OF FURAN IN FOOD}

Because of its high volatility, headspace sampling is the most suitable method for analyzing furan. To avoid furan losses during sample preparation, sampling and extraction have to be performed under cold conditions. Samples of food can be weighed directly in the headspace vial; after mixing and homogenization with water, the vial is sealed and heated to promote volatilization of the analyte in the headspace phase, thereby achieving equilibrium between the liquid and gaseous phases. Automated vial shaking may be used to reduce a prolonged time until equilibration. ${ }^{8}$ In addition, $\mathrm{pH}$ of the samples must be taken into account because, depending on the temperature of incubation, acidic or basic conditions may affect furan concentrations determined in food samples. ${ }^{9}$ To avoid the formation of extra furan during the analytical procedure as a consequence of heating, most research laboratories have settled on an incubation temperature of $50^{\circ} \mathrm{C}$ or below, ${ }^{10,11}$ even though no 
physical losses from the headspace vial or decomposition of the furan by heating have been reported. ${ }^{9}$ The headspace gas is sampled and vapor injected into a gas chromatograph. The subsequent detection of furan is carried out by mass spectrometry or by nonselective means such as flame ionizing detection. ${ }^{12}$ The chromatographic separation is mainly performed on PLOT $\mathrm{Q}$ (porous layer open tubular) columns or equivalents; these columns have a bonded porous polymer based on polystyrene and divinylbenzene, which is relatively inert and stable in water. The solid stationary phase, with a small particle size, provides stronger adsorption characteristics than columns using a liquid stationary phase; therefore, compounds with a lower boiling point elute well after those with a higher boiling point. These kinds of columns allow adequate retention and separation of furan from other volatile compounds. ${ }^{10}$ Table 110.1 summarizes some procedures specially dedicated to furan analysis of coffee.

The most common analysis for determining the amounts of furan in food is the headspace-gas chromatography-mass spectrometry (HS-GC-MS) method developed by the US Food and Drug Administration. ${ }^{5}$ This method basis quantification on standard additions using deuterated furan $\left(\mathrm{d}_{4}\right.$-furan) as an internal standard. Headspace of sealed vials containing the tested samples mixed with water are fortified with a standard furan solution at concentrations $0.5,1.0$, and 2.0 times the estimated furan content in the food sample. In addition, a standard $\mathrm{d}_{4}$-furan solution at a concentration similar to that of the estimated furan content in the food sample is added to each vial. Automated headspace sampling followed by GC-MS analysis is used to detect furan and $\mathrm{d}_{4}$-furan in the selected ion monitoring mode. Furan is quantified using a standard addition curve, where the concentrations of furan in the fortified test portions are plotted against the furan $/ \mathrm{d}_{4}$-to-furan ratio. The different standards are identified and quantified using the ions $m / z 68$ and 39 for furan and $m / z 72$ and 42 for $\mathrm{d}_{4^{-}}$ furan (Figure 110.2). For most foods, limit of quantification ranges from 0.04 to $100 \mu \mathrm{g} / \mathrm{kg}$ and limit of detection (LOD) from 0.03 to $40 \mu \mathrm{g} / \mathrm{kg}$; the highest values have been reported for coffee (limit of quantification: 0.10$100.00 \mu \mathrm{g} / \mathrm{kg}$; LOD: $0.05-40.00 \mu \mathrm{g} / \mathrm{kg}){ }^{6}$ Quantification of furan using only a furan-to-d4-furan ratio may also be achieved. ${ }^{27}$ The standard addition method is selected for furan quantification to avoid matrix effects in the different food samples. However, several authors have not found any advantages of using this method over an external calibration method. ${ }^{20,28}$

Furan can also be analyzed by a solid-phase microextraction (SPME) method in combination with GCMS. This procedure was developed by researchers from the National Food Processors Association and Nestlé Research Centre. ${ }^{15,29,30}$ SPME uses a fiber coated with
TABLE 110.1 Summary of Procedures for Analyzing Furan in Coffee

\begin{tabular}{|c|c|c|c|c|}
\hline Method & Column & $\begin{array}{l}\text { Recovery } \\
(\%)\end{array}$ & $\begin{array}{l}\text { LOD/LOQ } \\
\text { (ng/g) }\end{array}$ & References \\
\hline \multirow[t]{3}{*}{$\begin{array}{l}\text { SPME/ } \\
\text { GC-MS }\end{array}$} & $\begin{array}{l}\text { HP-Plot Q } \\
15 \times 0.32 \mathrm{~mm} \\
20 \mu \mathrm{m}\end{array}$ & $103.8 \pm 0.02$ & $0.4 / 1.4$ & 13 \\
\hline & $\begin{array}{l}\text { CP-Porabond Q } \\
25 \times 0.32 \mathrm{~mm} \text {, } \\
5 \mu \mathrm{m}\end{array}$ & $78-89$ & - & 14 \\
\hline & $\begin{array}{l}\text { HP-Plot Q } \\
15 \times 0.32 \mathrm{~mm} \\
20 \mu \mathrm{m}\end{array}$ & 86.6 & $17 / 43^{a}$ & 15 \\
\hline \multirow[t]{5}{*}{$\begin{array}{l}\text { HS } \\
\text { SPME/ } \\
\text { GC-MS }\end{array}$} & $\begin{array}{l}\text { SGE BPX VOL } \\
30 \times 0.25 \mathrm{~mm} ; \\
1.4 \mu \mathrm{m}\end{array}$ & 92.8-102 & $0.002 / 0.006$ & 16 \\
\hline & $\begin{array}{l}\text { HP-INNOWAX } \\
60 \times 0.25 \mathrm{~mm} ; \\
0.25 \mu \mathrm{m}\end{array}$ & 76-101 & $\begin{array}{l}0.2 / 0.8 \\
\text { (green } \\
\text { coffee) } \\
3 / 10 \text { (coffee } \\
\text { brew) }\end{array}$ & 17 \\
\hline & $\begin{array}{l}\mathrm{BX} \text { volatile } \\
60 \times 0.25 \mathrm{~mm} \\
1.4 \mu \mathrm{m}\end{array}$ & - & $0.02-0.12 /-$ & 11 \\
\hline & $\begin{array}{l}\text { BPX volatiles } \\
60 \times 0.25 \mathrm{~mm} ; \\
1.4 \mu \mathrm{m}\end{array}$ & - & $70 / 250^{b}$ & 18 \\
\hline & $\begin{array}{l}\text { HP-Plot Q } \\
15 \times 0.32 \mathrm{~mm} \\
20 \mu \mathrm{m}\end{array}$ & $75.7-103$ & $0.05 / 0.17$ & 19 \\
\hline \multirow[t]{7}{*}{$\begin{array}{l}\text { HS } \\
\text { GC-MS }\end{array}$} & $\begin{array}{l}\text { Plot } Q \\
30 \times 0.25 \mathrm{~mm} \\
20 \mu \mathrm{m}\end{array}$ & - & $-/ 0.5-2$ & 20 \\
\hline & $\begin{array}{l}\text { Plot HT-Q } \\
12.5 \times 0.32 \mathrm{~mm} ; \\
0.45 \mu \mathrm{m}\end{array}$ & - & $0.1 /$-c $^{-}$ & 21 \\
\hline & $\begin{array}{l}\text { HP-Plot Q } \\
15 \times 0.32 \mathrm{~mm} \\
20 \mu \mathrm{m}\end{array}$ & $83-97$ & $2 / 4$ & 22 \\
\hline & $\begin{array}{l}\text { HP-Plot Q } \\
30 \times 0.32 \mathrm{~mm} ; \\
20 \mu \mathrm{m}\end{array}$ & 89.4-108 & $\begin{array}{l}0.2-0.9 / \\
0.6-2.9\end{array}$ & 23 \\
\hline & $\begin{array}{l}\text { HP-Plot Q } \\
15 \times 0.32 \mathrm{~mm} ; \\
20 \mu \mathrm{m}\end{array}$ & $83-97$ & $2 /-$ & 24 \\
\hline & $\begin{array}{l}\text { HP-Plot Q } \\
30 \times 0.32 \mathrm{~mm}\end{array}$ & - & $1 / 4$ & 25 \\
\hline & $\begin{array}{l}\text { HP-Plot Q } \\
15 \times 0.32 \mathrm{~mm} ; \\
20 \mu \mathrm{m}\end{array}$ & 90-120 & - & 26 \\
\hline
\end{tabular}

Table shows several procedures for analysis of furan in coffee according to different authors. Units are expressed as

apicograms.

bicograms per gram.

${ }^{c}$ nanograms per milliliter. 

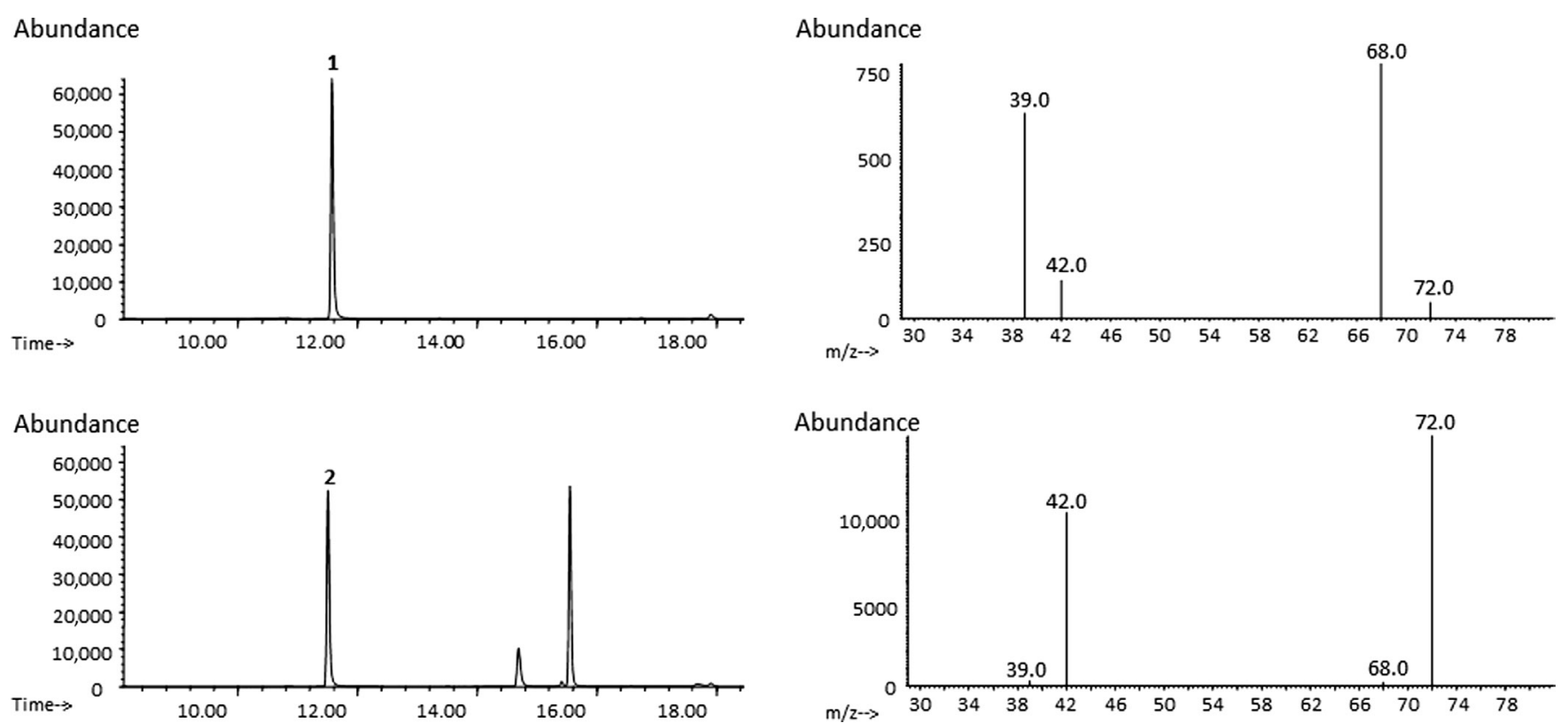

FIGURE 110.2 Ion chromatograms and mass spectra of furan (1) and d4-furan (2) extracted from headspace-gas chromatography-mass spectrometry. Identification and quantification of the different standards were performed using the ions $\mathrm{m} / \mathrm{z} 68$ and 39 for furan (1) and $\mathrm{m} / \mathrm{z} 72$ and 42 for d4-furan (2).

a liquid (polymer), a solid (sorbent), or a combination of both. The fiber coating is exposed to the headspace vapors to absorb volatiles (absorption in the case of liquid coatings and adsorption in the case of solid coatings). After that, the SPME fiber is inserted directly into the gas chromatograph for furan desorption and analysis. Several fibers have been evaluated to obtain the best sensibility and selectivity for determining furan. For instance, Carboxen ${ }^{\mathrm{TM}} /$ polydimethylsiloxane have produced the best results. 3,18 According to Crews and Castle, ${ }^{10}$ the SPME method allows concentration of the sample, which leads to a higher sensibility.

\subsection{FURAN IN COFFEE}

Among adults, coffee consumption may be the highest contributor to furan exposure from dietary sources. ${ }^{23,31,32}$ Furan is present in coffee as part of the volatile aroma components generated during roasting, including alcohols, esters, aldehydes, ketones, pyrazines, and sulfur compounds, among others ${ }^{33}$; thus, furan concentrations are very low or not detected in green coffee, whereas concentrations up to $7000 \mu \mathrm{g} / \mathrm{kg}$ have been observed in roasted ground coffee. ${ }^{26}$

Sucrose, glucose, and linoleic and linolenic acids are potential precursors of furan formation in roasted coffee because these compounds are found in significant amounts in green coffee. Ascorbic acid, however, is not detected in green coffee samples and, therefore, it does not seem to be an important precursor of furan in roasted

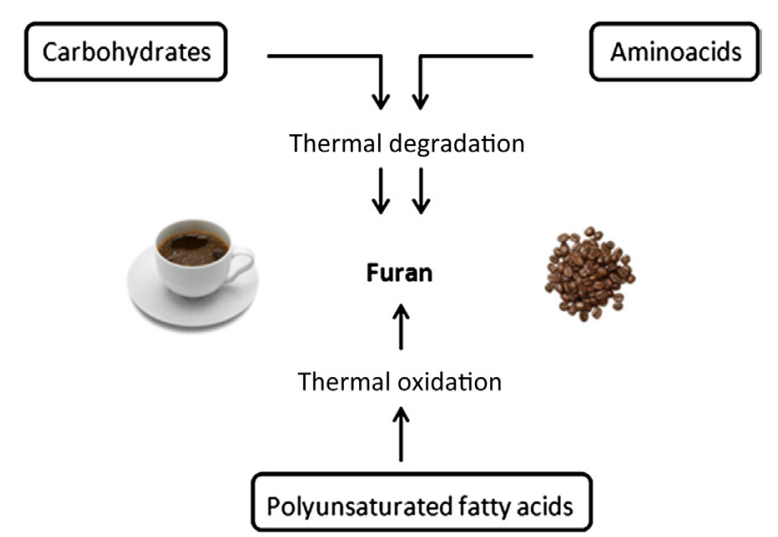

FIGURE 110.3 Possible routes of furan formation in coffee.

coffee. ${ }^{17}$ Furan is formed by pyrolysis of precursors during roasting. Possible routes for furan formation in coffee are summarized in Figure 110.3. Key intermediates are acetaldehyde and glycolaldehyde, which produce furan after aldol condensation, cyclization, and dehydration.

During roasting, furan formation depends on green coffee types and roasting conditions. ${ }^{11,20}$ From roasting to the cup, furan concentrations decrease because of the high volatility and low water solubility of furan (Figure 110.4). Thus, through grinding, packaging, storage, and brewing procedures, concentrations of furan decrease; therefore, the real exposure of the consumer to furan should be estimated. This fact should be considered when estimations of furan consumption from coffee are investigated. Data available in the literature 


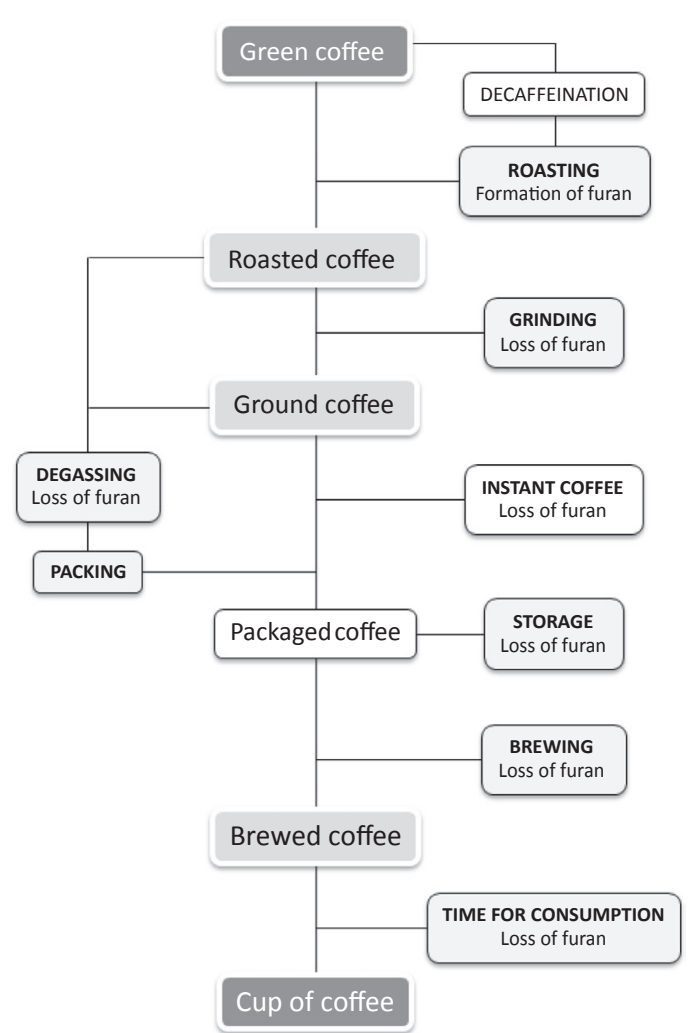

FIGURE 110.4 General scheme of the steps from green coffee to the cup.

of furan concentrations for the different coffee products are described in Table 110.2.

\subsubsection{Roasting}

As mentioned above, concentrations of furan in green coffee are very low or undetectable. ${ }^{17,20,25}$ Green coffee beans contain high concentrations of furan precursors and, therefore, furan is formed during roasting. ${ }^{34}$ Furan formation can be affected by either or both the type of coffee and roasting conditions, which in the latter would include parameters such as time and temperature. ${ }^{11,20}$ In this context, Arisseto et al. ${ }^{17}$ described significantly higher furan values in Robusta coffee with each roasting degree compared with Arabica coffee, although no correlations between precursors and furan formation were observed, probably because other factors such as $\mathrm{pH}$ might also have been involved. Contrary to this, Guenther et al. ${ }^{26}$ did not find any differences in furan concentrations in Robusta and Arabica coffee samples of different origins and roasted for the same length of time. Regarding roasting conditions, it has been reported that furan concentrations significantly increase with the intensity of roasting. This fact has been demonstrated by Arisseto et al. and by Guenther et al. who studied furan formation during the roasting of green coffee and showed that darker roasting colors and longer roasting
TABLE 110.2 Furan Concentrations in Coffee Products

\begin{tabular}{|c|c|c|}
\hline Product & Furan Concentration (ng/g) & References \\
\hline Green coffee & Not detected & $17,20,25$ \\
\hline \multirow[t]{4}{*}{ Roasted coffee } & $1322-3027$ & 20 \\
\hline & $911-5852$ & 17 \\
\hline & $3510-6100$ & 25 \\
\hline & $2000-7000$ & 26 \\
\hline \multirow[t]{4}{*}{ Ground coffee } & $959-5938$ & 20 \\
\hline & $790-3390$ & 25 \\
\hline & $1200-4200$ & 26 \\
\hline & $57.3-587.3$ & 16 \\
\hline \multirow[t]{9}{*}{ Brewed coffee } & $\begin{array}{l}20-66^{\mathrm{a}} \text { (Drip coffee maker) } \\
43-146^{\mathrm{a}} \text { (Espresso machine) } \\
117-344^{\mathrm{a}} \text { (Espresso blend from coffee } \\
\text { capsules) } \\
68-102^{\mathrm{a}} \text { (Lungo blend from coffee } \\
\text { capsules) }\end{array}$ & 11 \\
\hline & $20.2-29.0$ & 13 \\
\hline & 13-199 & 20 \\
\hline & $<10-288$ & 17 \\
\hline & $\begin{array}{l}57-115^{\text {a }} \text { (Automatic coffee machine) } \\
9-33^{\mathrm{a}} \text { (Home machine) } \\
17-24^{\mathrm{a}} \text { (Manual machine) } \\
33-66^{\mathrm{a}} \text { (French press machine) }\end{array}$ & 25 \\
\hline & $37.4-84.2$ & 23 \\
\hline & 58 & 18 \\
\hline & $10-35^{\mathrm{a}}$ & 26 \\
\hline & $\begin{array}{l}\text { 36.0-131.1 (Moka pot) } \\
24.5-305 \text { (Espresso machine) }\end{array}$ & 16 \\
\hline \multirow[t]{4}{*}{ Instant coffee } & $44-2150$ & 20 \\
\hline & $240-2200$ & 25 \\
\hline & 1.5 & 23 \\
\hline & 2279 & 18 \\
\hline \multirow{5}{*}{$\begin{array}{l}\text { Instant coffee } \\
\text { beverage }\end{array}$} & $12-35^{\mathrm{a}}$ & 11 \\
\hline & $2.1-6.4$ & 13 \\
\hline & $1-51.3$ & 20 \\
\hline & $3-25^{a}$ & 25 \\
\hline & 12.6 & 18 \\
\hline
\end{tabular}

Table shows furan levels in coffee products according to different authors. Units are expressed as

ananograms per milliliter.

times tend to increase furan concentrations. Thus, when coffee beans were roasted from a lighter to a darker color, furan concentrations increased from 985 to $4345 \mu \mathrm{g} /$ $\mathrm{kg}$ in Arabica coffee and from 1722 to $5697 \mu \mathrm{g} / \mathrm{kg}$ in Robusta coffee. Furan concentrations ranging from 2000 
to $7000 \mu \mathrm{g} / \mathrm{kg},{ }^{26} 3600-6100 \mathrm{ng} / \mathrm{g},{ }^{25}$ and $1322-3027 \mathrm{ng} / \mathrm{g}^{20}$ have been reported for roasted coffee beans.

Decaffeination is carried out before roasting, whereby caffeine is removed from green coffee beans using steaming to open the pores and organic solvents. ${ }^{35}$ According to Silvarolla et al. ${ }^{36}$ key flavor components can be lost during the decaffeination process. However, no differences in furan content have been found when comparing decaffeinated with regular coffee. ${ }^{25,31}$

\subsubsection{Grinding}

After roasting and before the brewing procedure, coffee beans are ground with the objective of decreasing the size of the particles and improving the extraction of the coffee substances. Grinding causes significant losses of volatile aroma compounds, the amount of which are dependent on the grinding conditions. According to Guenther et al. ${ }^{26}$ grinding procedures may generate furan losses of about $50 \%$, which is influenced by the final particle size of ground coffee. Concentrations from 2000 to $7000 \mu \mathrm{g} / \mathrm{kg}$ in roasted whole beans have been demonstrated to decrease up to $1200-4200 \mu \mathrm{g} / \mathrm{kg}$ after grinding. ${ }^{26}$ Values between 959 and $5938 \mathrm{ng} / \mathrm{g}$ for ground roasted coffee have been described. ${ }^{20}$

\subsubsection{Degassing}

Before being vacuum packed, roasted and ground coffees need to be degassed to eliminate the carbon dioxide generated in the coffee beans as a consequence of roasting reactions; then carbon dioxide must be prevented from escaping inside the vacuum pack. This process again may reduce furan concentrations. A degassing process of up to $4 \mathrm{~h}$ can result in a furan reduction of around $20 \% .^{26}$

\subsubsection{Storage Conditions}

Another factor to consider is the coffee storage conditions, both for coffee beans before grinding as well as for coffee products after packaging. Studies of furan stability or losses in coffee during different storage conditions have been carried out by several authors. Guenther et al. ${ }^{26}$ simulated pilot-scale trials of typical commercial plant process conditions and reported that storage of roasted whole beans in open bags for up to $96 \mathrm{~h}$ at ambient temperature and at $40^{\circ} \mathrm{C}$ before grinding seemed not to affect furan concentrations. In a similar way, furan concentrations in unopened packaged roasted coffee stored at $4{ }^{\circ} \mathrm{C}$ and at ambient temperature did not seem to significantly change during the first 3 months of shelf-life.

Regarding consumer handling, it is common that, once opened, packaged coffee is tightly resealed over the consumption period. In these conditions, furan concentrations remain almost constant if coffee is maintained in a refrigerator, thus preserving the initial and desired aroma levels, whereas these decrease by $20-25 \%$ in both whole beans and ground coffee when products are stored at ambient temperatures. ${ }^{26}$

\subsubsection{Brewing Procedure}

Furan concentrations in coffee brews depend on the furan content of the roasted coffee powder, coffee-towater ratio used for preparing coffee beverages, as well as the size of the ground coffee particles; if brews are prepared from fine-grained coffee, furan concentrations are higher than those from normal grains. ${ }^{22}$ Brewing conditions include parameters such as contact time between coffee and water, brewing temperature or pressure, and the system used for preparing coffee beverages. These parameters, which are defined by the brewing machine used, influence the transfer rate of furan from the coffee powder into the coffee brew, the losses of furan through the brewing procedure, and therefore the final furan concentration in the coffee drink. ${ }^{37}$

The highest concentrations of furan in coffee brews have been observed in espresso-type machines and the lowest when coffee is made with a home drip coffee maker and by manual brewing. ${ }^{11,25}$ Automatic coffee machines produce brews with higher concentrations of furan because a higher ratio of coffee powder to water is usually used, giving a lower dilution factor. Espresso coffee is a concentrated beverage of around $20-40 \mathrm{ml}$ prepared by applying hot water at high pressure through finely ground coffee. The higher pressure applied in an espresso machine compared with that in a home drip maker also increases the extraction of furan from the coffee powder; in addition, the closed system favors retention of furan. ${ }^{11}$ Moreover, preparation of a brew in an espresso machine requires less time than that required with a home drip maker, which also decreases the furan losses during the brewing procedure. ${ }^{35}$ This is another fact that should be considered in the coffee brew preparation procedure: if ground coffee is boiled with water before filtration, furan losses can be higher, therefore resulting in a larger reduction and higher volatilization of furan in these beverages. ${ }^{17}$ Lungo coffee has a smaller concentration, characterized by a higher volume compared with espresso coffee (100-250 ml), and usually is consumed with milk or cream. For this reason, furan concentration in this kind of drink shows lower values (Table 110.2). Furan concentrations of $57-115 \mathrm{ng} / \mathrm{g}$ in coffee brews obtained from an automatic coffee machine have been reported, decreasing when the beverage is prepared in a home machine (9-33ng/g), in a manual machine (17-24ng/g), or in a French press (33-66ng/g). ${ }^{25}$ Other ranges of furan concentrations in brewed coffee$4.3-76.1 \mathrm{ng} / \mathrm{g}^{38}$ and $<10-288 \mu \mathrm{g} / \mathrm{kg}^{17}$-also have been described. 
Coffee brewing and extraction methods also depend on geographic and cultural habits as well as personal preferences. For instance, Turkish coffee is prepared by infusing coffee in hot water for a few minutes, ${ }^{39}$ Italian coffee is characterized by a high concentration of coffee solids in the brews, ${ }^{22}$ and American coffee is typically larger and softer with a larger amount of water. These facts also have to be taken into account when furan content in coffee is evaluated.

Because of the high volatility of furan, losses of up to 91\% from roasted coffee can be produced through preparation of a coffee drink. ${ }^{25}$ Experiments studying the transfer rate of furan from the coffee powder into the coffee brew have been carried out by several authors. Zoller et al. ${ }^{20}$ found a transfer rate of $29 \%$ of the furan content in coffee powder when an espresso coffee $(65 \mathrm{ml})$ was prepared in a semiautomatic espresso machine. This rate was $32 \%$ when a normal coffee $(130 \mathrm{ml})$ was obtained. In agreement with these results, Kuballa et al. ${ }^{25}$ reported a transfer rate of $30 \%$ in coffee drinks obtained from powdered coffee; $9 \%$ was the mean value for coffees prepared by the infusion method, $22 \%$ by the French method, and $32 \%$ by an automatic machine. This transfer rate presented a range of $4-49 \%$ when coffee brew was obtained from roasted coffee beans. La Pera et al. ${ }^{16}$ reported that furan was reduced by $57 \%$ after infusion in hot water for $5 \mathrm{~min}$ (Turkish coffee), and by $67 \%$ and $63 \%$ when brewing coffee were prepared using a moka pot and an automatic espresso machine (Italian coffee), respectively. Other percentages such as $50-60 \%,{ }^{26} \quad 63-113 \%{ }^{31}$ and $50-98 \% 17$ for furan transferred from the powder to the brewed coffee have also been reported.

As mentioned above, the temperature of water and contact time between coffee and water during the brewing are determinants of furan losses through the coffee preparation and, therefore, of furan content in the coffee beverage. In this context, La Pera et al. ${ }^{16}$ reported that furan concentrations in coffee powder decreased by $35 \%$ when infusion of coffee was prepared in hot water at $80^{\circ} \mathrm{C}$ after $1 \mathrm{~min}$, by $60 \%$ after $5 \mathrm{~min}$, and by $96 \%$ after $10 \mathrm{~min}$. Furan concentrations decreased below the LOD when coffee infusion was prolonged up to $20 \mathrm{~min}$. This reduction of furan concentrations was by $60 \%, 91 \%$, and lower than the LOD when coffee infusion was prepared in hot water at $98^{\circ} \mathrm{C}$ after 1,5 , and $10 \mathrm{~min}$, respectively.

Furan concentrations of $117-244 \mathrm{ng} / \mathrm{ml}$ in coffee beverages obtained from coffee capsules have recently been described. ${ }^{11}$ According to these authors, these concentrations, which were higher than those obtained in espresso brews of regular ground coffee, could be attributed to the prevention of furan loss during handling as a result of the hermetic seal of the capsules. Moreover, the higher pressure applied by the coffee machine may favor the extraction of furan from the ground coffee.

\subsubsection{Instant Coffee}

Furan concentrations in instant coffee depend on the content in the roasted coffee from which the instant coffee is produced, as well as on the processes involved. These processes include treatment of the roasted ground coffee with hot water and high pressure to extract watersoluble compounds and concentration and drying, which lead to lower concentrations of furan compared with those of roasted and ground coffee. 35,40 Concentrations of $122-1330,{ }^{38} 2279,{ }^{18} 44-2150,{ }^{20}$ and $240-2220 \mathrm{ng} /$ $\mathrm{g}^{25}$ have been described in instant coffee, whereas coffee beverages prepared from soluble coffees have been reported to contain furan concentrations of $<2.4-6.6,38$ $12.6,{ }^{18} 1-51.3,{ }^{20}$ and $3-25 \mathrm{ng} / \mathrm{g} .{ }^{25}$

\subsubsection{Cup of Coffee: Coffee Ready to Drink}

For the evaluation of furan concentrations in coffee, the way the coffee beverage is kept before its consumption should also be considered. It is common that coffee beverages brewed in drip filter machines are kept hot on a heating plate for a longer period after brewing, causing furan losses, depending on time, temperature, and type of coffee machine. In this context, Guenther et al. ${ }^{26}$ observed that coffee brew kept hot for $30 \mathrm{~min}$ decreased the furan content by $35 \%$, and after $60 \mathrm{~min}$ the losses were approximately $50 \%$ of the initial concentrations, as measured immediately after brewing.

Ultimately, furan can be partially evaporated in the cup during consumption, normally because coffee is too hot directly after brewing and consumers wait until the beverage cools down. ${ }^{40}$ Therefore, because furan losses are produced after brewing and before consumption, more reliable data about furan consumption from coffee are required to assess the exposure of humans to furan. Different assays have been performed to study the impact of coffee production processes and consumer handling on furan concentrations in a cup of coffee. Several authors have carried out experiments with coffee samples exposed to the atmosphere at room temperature for various lengths of time, and different results have been reported: Zoller et al. ${ }^{20}$ observed losses of furan of about $50 \%$ after $1 \mathrm{~h}$, Goldman et al. ${ }^{15}$ described losses of $35 \%$ after $4 \mathrm{~h}$ (concentrations decreased from 22.4 to $8.0 \mu \mathrm{g} / \mathrm{kg}$ ), and Guenther et al. ${ }^{26}$ showed reductions of $25 \%$ after $30 \mathrm{~min}$, assuming that losses of approximately $10 \%$ occur within the first few minutes after the preparation of the cup of coffee. In a similar way, Kim et al. ${ }^{13}$ reported that furan concentrations decreased by $24 \%$ after allowing a mug of instant coffee to stand for 1-5 min at room temperature without a lid. After $20 \mathrm{~min}$, furan concentrations in brewed coffee decreased from 29.0 to $18.5 \mathrm{ng} / \mathrm{g}$ if the lid of the mug was open and from 29.0 to $23.7 \mathrm{ng} / \mathrm{g}$ if the lid was closed. 
On the other hand, higher furan concentrations in latte coffee $(217 \mu \mathrm{g} / \mathrm{kg})$, compared with those in espresso coffee $(188 \mu \mathrm{g} / \mathrm{kg})$ or regular coffee $(226 \mu \mathrm{g} / \mathrm{kg})$, have been reported. ${ }^{38}$ This fact may be because of a higher degree of retention caused by the larger total volume in latte coffee, the fat in the milk, and the froth on the top.

Anese and Suman ${ }^{41}$ recently published a review of the mitigation strategies of furan in food. They described two mitigation procedures-those designed to prevent furan formation and those associated with removal interventions-with the purpose of removing the already-formed furan from the food product. In the case of coffee samples, all the processes to which the coffee is subjected-from roasting to the cup-which are described in the present chapter, allow the reduction of furan concentrations, thus exposing consumers to lower amounts of furan.

\subsection{SUMMARY POINTS}

- Furan is a highly volatile compound present in many foods and drinks as a result of thermal treatment during processing.

- Because of its high volatility, headspace sampling is the most suitable method for analyzing furan.

- Methods of analyzing furan in food include HS-GCMS and SPME in combination with GC-MS.

- Coffee consumption may be the highest contributor to furan exposure from dietary sources among adults.

- Furan is present in coffee as part of the volatile aroma components generated during roasting.

- From roasting to the cup, furan concentrations decrease because of the high volatility and low water solubility of furan.

- Through grinding, packaging, storage, and brewing procedures, furan concentrations decrease, so the real exposure of the consumer to furan should be estimated.

\section{References}

1. Maga JA. Furans in food. CRC Crit Rev Food Sci Nutr 1979;1:355-400.

2. European Food Safety Authority (EFSA). Report of the scientific panel on contaminants in the food chain on provisional findings on furan in food. EFSA J 2004;137(1). http: / /www.efsa.europa.eu/ en/scdocs/doc/137.pdf [accessed 01.03.13].

3. Yaylayan VA. Precursors, formation and determination of furan in food. J Verbrauch Lebensm 2006;1:5-9.

4. IARC (Internacional Agency for Research on Cancer). IARC monographs on the evaluation of carcinogenic risk to humans. Dry cleaning, some chlorinated solvents and other industrial chemicals, vol. 63. Lyon: France; 1995. 393-407.

5. US Food and Drug Administration (US FDA). Exploratory data on furan in food. US Food and Drug Administration; 2004. http:/ /ww w.fda.gov/ohrms/dockets/ac/04/briefing/4045b2_09_furan $\% 20$ data.pdf [accessed 20.03.13].
6. European Food Safety Authority (EFSA). Update of results on the monitoring of furan levels in food. EFSA J 2010;8:1702. http:/ /www. efsa.europa.eu/en/scdocs/doc/1702.pdf [accessed 11.03.13].

7. Food and Agricultural Organisation/World Health Organization (FAO/WHO). Evaluation of certain contaminants in food. Seventysecond report of the Joint FAO/WHO Expert Committee on Food Additives. World Health Organisation; 2011http:/ / whqlibdoc.who. int/trs/WHO_TRS_959_eng.pdf [accessed 04.03.13].

8. Becalski A, Forsyth D, Casey V, Lau BPY, Pepper K, Seaman S. Development and validation of a headspace method for determination of furan in food. Food Addit Contamin 2005;22:535-40.

9. Crews C, Hasnip S, Roberts DPT, Castle L. Factors affecting the analysis of furan in heated foods. Food Addit Contamin 2007; 24:108-13.

10. Crews C, Castle L. A review of the occurrence, formation and analysis of furan in heat-processed foods. Trends Food Sci Tech 2007; 18:365-72.

11. Altaki MS, Santos FJ, Galceran MT. Occurrence of furan in coffee from Spanish market: contribution of brewing and roasting. Food Chem 2011;126:1527-32.

12. Vranová J, Ciesarová Z. Furan in food - a review. Czech J Food Sci 2009;27:1-10.

13. Kim TK, Lee YK, Park YS, Lee KG. Effect of cooking or handling conditions on the furan levels of processed foods. Food Addit Contam 2009;26:767-75.

14. Van Lancker F, Adams A, Owczarek A, Meulenaer B. Impact of various food ingredients on the retention of furan in foods. Mol Nutr Food Res 2009;53:1505-11.

15. Goldmann T, Périsset A, Scanlan F, Stadler RH. Rapid determination of furan in heated foodstuffs by isotope dilution solid phase micro-extraction-gas chromatography-mass spectrometry (SPMEGC-MS). Analyst 2005;130:878-83.

16. La Pera L, Liberatore A, Avellone G, Fanara S, Dugo G, Agozzino P. Analysis of furan in coffee of different provenance by head space solid phase micro extraction gas chromatography-mass spectrometry: effect of brewing procedures. Food Addit Contamin 2009;26:786-92.

17. Arisseto AP, Vicente E, Soares Ueno M, Verdiani Tfouni SA, De Figueiredo Toledo MC. Furan levels in coffee as influenced by species, roast degree, and brewing procedures. J Agric Food Chem 2011;59:3118-24.

18. Altaki MS, Santos FJ, Galceran MT. Analysis of furan in foods by headspace solid-phase microextraction-gas chromatography-ion trap mass spectrometry. J Chromatogr A 2007;1146:103-9.

19. Liu YT, Tsai SW. Assessment of dietary furan exposures from heat processed foods in Taiwan. Chemosphere 2010;79:54-9.

20. Zoller O, Sager F, Reinhard H. Furan in food: headspace method and product survey. Food Addit Contamin 2007;24:S91-107.

21. Senyuva HZ, Gökmen V. Analysis of furan in foods. Is headspace sampling a fit-for-purpose technique? Food Addit Contam 2005;22:1198-202.

22. Crews C, Roberts D, Lauryssen S, Kramer G. Survey of furan in foods and coffees from five European Union countries. Food Addit Contamin Part B 2009;2:95-8.

23. Morehouse KM, Nyman PJ, McNeal TP, Dinovi MJ, Perfetti GA. Survey of furan in heat processed foods by headspace gas chromatography/mass spectrometry and estimated adult exposure. Food Addit Contam 2008;25:259-64.

24. Hasnip S, Crews C, Castle L. Some factors affecting the formation of furan in heated foods. Food Addit Contamin 2006;23:219-27.

25. Kuballa T, Stier S, Strichow N. Furan in kaffee und kaffeegetränken. Deut Lebensm-Rundschau 2005;101:229-35.

26. Guenther H, Hoenicke K, Biesterveld S, Gerhard-Rieben E, Lantz I. Furan in coffee: pilot studies on formation during roasting and losses during production steps and consumer handling. Food Addit Contamin Part A 2010;27:283-90. 
27. Reinhard H, Sager F, Zimmermann H, Zoller O. Furan in foods on the Swiss market - method and results. Mitt Leb Hyg 2004;95:532-5.

28. Jestoi M, Jävinen T, Järvenpää $E$, Tapanainen $H$, Virtanen $S$, Peltonen K. Furan in the baby-food simples purchased from the Finnish markets. Determination with SPME-GCMS. Food Chem 2009;117:522-8.

29. Ho IP, Yoo SJ, Tefera S. Determination of furan levels in coffee using automated solid-phase microextraction and gas chromatography/mass spectrometry. J AOAC Int 2005;88:574-6.

30. Bianchi F, Careri M, Mangia A, Musci M. Development and validation of a solid phase microextraction-gas chromatography-mass spectrometry method for the determination of furan in baby-food. J Chromatogr A 2006;1102:268-72.

31. European Food Safety Authority (EFSA). Results on the monitoring of furan levels in food. European Food Safety Authority; 2009. EFSA Scientific Report 304, 1-23. http:/ / www.efsa.europa.eu/en/scdocs / doc/304r.pdf [accessed 20.03.13].

32. Mesias M, Guerra-Hernandez E, Garcia-Villanova B. Estimation of exposure to furan in the Spanish population. Int J Food Sci Nutr 2012;63:16-22.

33. Merritt C, Bazinet ML, Sullivan JH, Robertson DH. Mass spectrometric determination of the volatile components from ground coffee. J Agric Food Chem 1963;11:152-5.
34. Murkovic M, Derler K. Analysis of amino acids and carbohydrates in green coffee. J Biochem Biophys Methods 2006;69:25-32.

35. Farah F. Coffee constituents. In: Chu YF, editor. Coffee. Emerging health effects and disease prevention. Iowa, USA: John Wiley \& Sons, Inc. and the Institute of Food Technologists; 2012. pp. 21-58.

36. Silvarolla MB, Mazzafera P, Fazuoli LC. A naturally decaffeinated arabica coffee. Nature 2004;249:826.

37. Petraco M. The cup. In: Illy A, Viani R, editors. Espresso coffee: the science of quality. 2nd ed. Italy: Elsevier Academic Press; 2005. pp. 290-8.

38. European Food Safety Authority (EFSA). Furan in heat processed food products including home cooked food products and ready-to-eat products. European Food Safety Authority; 2009. EFSA Scientific Report. http:/ / www.efsa.europa.eu/en/supporting/doc/1e.pdf [accessed 20.03.13]

39. Fraňková A, Drábek O, Havlík J, Száková J, Vaněk A. The effect of beverage preparation method on aluminium content in coffee infusions. J Inorg Biochem 2009;103:1480-5.

40. Guenther H. Furan in coffee. In: Chu YF, editor. Coffee. Emerging health effects and disease prevention. Iowa, USA: John Wiley \& Sons, Inc. and the Institute of Food Technologists; 2012. pp. 307-18.

41. Anese M, Suman M. Mitigation strategies of furan and 5-hydroxymethylfurfural in food. Food Res Int 2013;51:257-64. 